University of Louisville ThinkIR: The University of Louisville's Institutional Repository

Electronic Theses and Dissertations

$8-2013$

\title{
Influence of Lonicera maackii on leaf litter decomposition and macroinvertebrate communities in an urban stream.
}

Catherine A. Fargen

University of Louisville

Follow this and additional works at: https://ir.library.louisville.edu/etd

\section{Recommended Citation}

Fargen, Catherine A., "Influence of Lonicera maackii on leaf litter decomposition and macroinvertebrate communities in an urban stream." (2013). Electronic Theses and Dissertations. Paper 427.

https://doi.org/10.18297/etd/427

This Master's Thesis is brought to you for free and open access by ThinkIR: The University of Louisville's Institutional Repository. It has been accepted for inclusion in Electronic Theses and Dissertations by an authorized administrator of ThinkIR: The University of Louisville's Institutional Repository. This title appears here courtesy of the author, who has retained all other copyrights. For more information, please contact thinkir@louisville.edu. 
INFLUENCE OF LONICERA MAACKII ON LEAF LITTER DECOMPOSITION AND MACROINVERTEBRATE COMMUNITIES IN AN URBAN STREAM

\author{
By \\ Catherine A. Fargen \\ B.S., University of Louisville, 2010 \\ A Thesis \\ Submitted to the Faculty of the \\ College of Arts and Sciences of the University of Louisville \\ in Partial Fulfillment of the Requirements \\ for the Degree of \\ Master of Science \\ Department of Biology \\ University of Louisville \\ Louisville, Kentucky
}

August 2013 

INFLUENCE OF LONICERA MAACKII ON LEAF LITTER DECOMPOSITION AND MACROINVERTEBRATE COMMUNITIES IN AN URBAN STREAM

By

Catherine A. Fargen

B.S., University of Louisville, 2010

A Thesis Approved on

July 12, 2013

by the following Thesis Committee:

Dr. Sarah Emery

Dr. Margaret Carreiro

Robert Forbes 


\section{ACKNOWLEDGEMENTS}

This study was funded in part by a grant from the University of Louisville Graduate Student Union. Lonicera maackii removal was performed by the Louisville Olmsted Parks Conservancy. Thanks to Major Waltman for assisting with numerous aspects of this project including site selection, map making, and background information on the parks. Thanks to my family and friends for their constant support, as well as assistance in the field and lab. Thanks to Farid Halahel and Jeff Masters for their help with invertebrate identification. Special thanks to Bob Forbes and Dr. Margaret Carreiro for being on my committee and for providing invaluable comments and advice. And

most of all, thanks to my advisor, Dr. Sarah Emery, whose patience and commitment to science are inspiring, and without whom I would not have entered the field of Ecology. 


\begin{abstract}
INFLUENCE OF LONICERA MAACKII ON LEAF LITTER DECOMPOSITION AND MACROINVERTEBRATE COMMUNITIES IN AN URBAN STREAM

Catherine Fargen

July 12, 2013
\end{abstract}

Lonicera maackii (amur honeysuckle) is an aggressive alien shrub that invades many habitats in the Eastern United States, including along streambanks. This study investigated the direct and indirect effects of L. maackii invasion on leaf litter decomposition in an urban stream by placing leaf litter packs of $L$. maackii and the native Acer saccharum (sugar maple) in stream segments invaded by or managed for L. maackii. We found L. maackii litter decomposed two times faster than native A. saccharum, and A. saccharum leaf litter supported a higher abundance of macroinvertebrates than $L$. maackii. Functional feeding groups of macroinvertebrates were also affected by the invasive species; significantly more scraper-gatherers were associated with $A$. saccharum litter, and predators were positively associated with both A. saccharum and invaded sites. Additional indirect effects of L. maackii presence along streambanks on leaf decomposition and macroinvertebrate communities were negligible, possibly due to overriding effects of urbanization. 


\section{TABLE OF CONTENTS}

PAGE

ACKNOWLEDGEMENTS .................................................

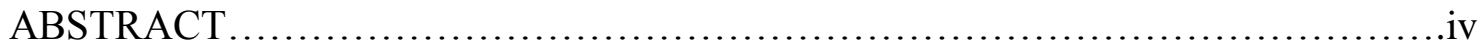

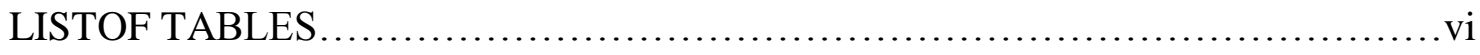

LIST OF FIGURES.................................................... vii

CHAPTER1:

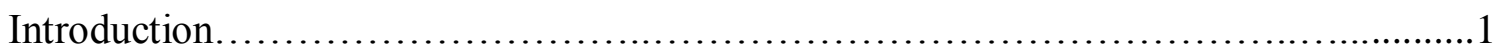

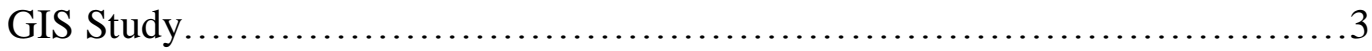

CHAPTER 2: The influence of Lonicera maackii on leaf litter decomposition and macroinvertebrate communities in an urban stream...................... 10

Introduction..................................................... 10

Methods................................................................ 14

Results.........................................................19

Discussion.......................................................20

Conclusion......................................................25

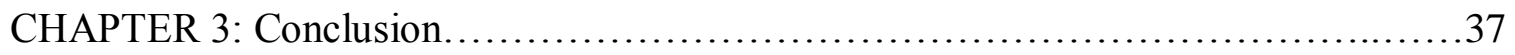

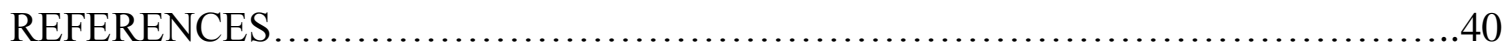

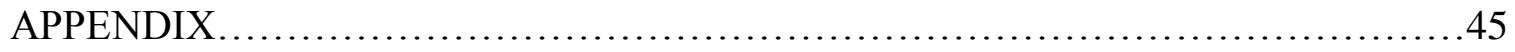

CIRRICULUM VITAE ......................................................46 


\section{LIST OF TABLES}

Table 2-1. K-values based on corrected AFDM data.............................26

Table 2-2. ANOVA table, F-statistics and p-values for ODM and AFDM.

Significant factors $(\mathrm{p}<0.05)$ are in bold. .............................. 27

Table 2-3. Statistics for abundance, morphotype richness, and diversity across all dates. Significant factors $(\mathrm{p}<0.05)$ are in bold............................... 28

Table 2-4. Statistics for abundance, morphotype richness, and diversity on day 49.

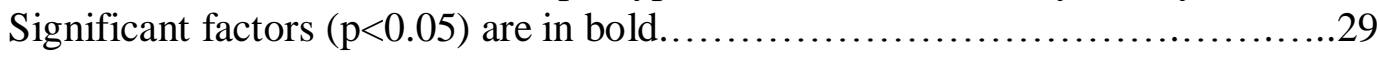

Table 2-5. Statistics for Functional Feeding Groups across all dates. Significant

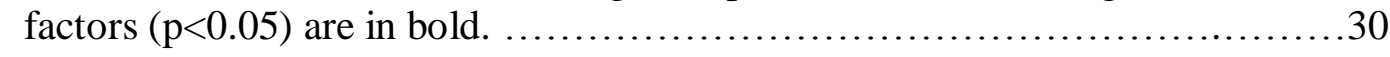

Table 2-6. Statistics for Functional Feeding Groups, Day 49. Significant factors

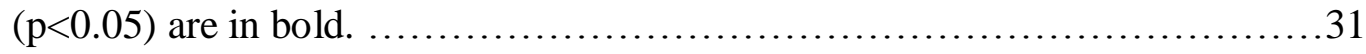




\section{LIST OF FIGURES}

Figure 1-1. Map of Beargrass Creek Watersheds and areas of Beargrass Creek adjacent to riparian $L$. maackii invasion....................................

Figure 1-2. Map of Beargrass Creek Watersheds and areas of Beargrass Creek adjacent to riparian $L$. maackii invasion including land use.....................8

Figure 1-3. Total stream length and percentage breakdown of L. maackii invasion and absence in Beargrass Creek watersheds....................................9

Figure 2-1. Map of field sites............................................. 26

Figure 2-2. Percent ODM (oven dry mass) and AFDM (ash-free dry mass) remaining, mass loss curve. Error bars indicate \pm 1 SE ......................27

Figure 2-3. Average macroinvertebrate abundance per site and average morphotype

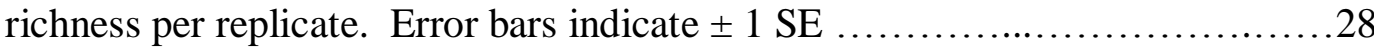

Figure 2-4. Average number of predators per treatment, day 49. Error bars indicate $\pm 1 \mathrm{SE}$

Figure 2-5. Average number of invertebrates per site per collection day, by FFG. Collector filterers and scraper gatherers are not represented due to low abundances 


\section{CHAPTER 1: INTRODUCTION}

Invasive species are non-native organisms that have the potential to cause economic, environmental, or human harm (Exec. Order No. 13112, 1999). The spread of invasive species has been speculated to be one of the greatest threats to biodiversity; one estimate suggests that invasive species are responsible for nearly half of the additions to the Threatened and Endangered species lists (Pimentel et al. 2005). The problem is also incredibly expensive. Restoration efforts and economic losses caused by invasive species in the U.S. alone cost nearly $\$ 120$ billion annually (Pimentel et al. 2005). Despite the efforts that are put into solving the problem of invasive species, many aspects of invasion remain unknown. In order to ensure that restoration and conservation resources are being used effectively, the causes, mechanisms, and outcomes of invasion must be better understood.

Lonicera maackii (amur honeysuckle, bush honeysuckle) is an exotic shrub that has wide reaching impacts throughout the ecosystems it invades. It out-competes native plants by having a prolonged growing season (Miller \& Gorchov 2004) and allelopathic compounds in the leaf and root tissues (Dorning \& Cipollini 2006). It has also been found to have ecosystem-level impacts by altering nutrient cycling dynamics (Blair \& Stowasser 2009) and influencing other trophic levels such as insect communities (Cipollini et al. 2008). Lonicera maackii was originally imported from Asia in the late 
$19^{\text {th }}$ century as an ornamental plant (Luken \& Thieret 1996) and to mitigate effects of erosion. Since then, L. maackii has spread throughout the Eastern United States; it is currently found in 28 states including Kentucky (USDA).

Lonicera maackii is well established throughout Jefferson County, KY. A system of highways throughout the county were built around 1970, during which time the Department of Transportation actively planted L. maackii along the verges (KYTC Projects Archive 2008). The plant likely then spread throughout the county via avian vectors that consume the berries. Cherokee Park, which lies in the heart of the county, became heavily invaded after a 1974 tornado destroyed many of the forested sections of the park (Carreiro \& Zipperer 2011). Over the past 7 years the Louisville Olmsted Parks Conservancy has invested about $\$ 3.5$ million dollars toward the eradication of L. maackii in parks throughout the county and has removed about 98\% in Cherokee Park (Waltman, pers. comm. 2013). Other parts of the city, including along many highway verges, remain invaded (Trammell \& Carreiro 2011).

The dichotomy between invaded and managed areas of the county presents a unique opportunity for L. maackii research, and several studies investigating various aspects of $L$. maackii invasion have been conducted in Cherokee and neighboring areas. For instance, Trammell et al. (2012) performed a study that compared the terrestrial decomposition of L. maackii and native Acer saccharum (sugar maple) leaf litter and found differential decay rates between the two species and an influence of presence of $L$. maackii invasion on those rates as well. Another study looked at arthropod abundance and diversity between $L$. maackii invaded and managed plots and found seasonal variation among treatments, with higher abundance and diversity in the removal plots 
during the spring season (Masters et al., in prep). One group investigated the unique color signature of L. maackii presence in Cherokee Park by a remote sensing study, and found that L. maackii presence could be determined with high accuracy from aerial photos using this technique (Shouse et al. 2012). To date, however, no studies have investigated the impacts of L. maackii presence or management on aquatic ecosystems in Cherokee Park and surrounding areas of Jefferson County.

\section{GIS study}

Beargrass Creek is a network of three converging waterways in Jefferson County. The Beargrass Creek watersheds encompass approximately $15 \%$ of the area of Jefferson Co. and also include the area of Cherokee Park. For this study, I wanted to assess the impacts of L. maackii invasion on stream ecosystem processes. In order to get an indication of these impacts at the larger, watershed scale, I performed a Geographic Information Systems (GIS) study mapping the extent of L. maackii invasion throughout the Beargrass Creek watersheds.

In order to estimate the extent of L. maackii invasion along riparian zones adjacent to streams in the Beargrass Creek watersheds, some background knowledge was required. A notable characteristic of L. maackii is the prolonged growing season, which results from relatively early leaf formation in the spring and late abscission in the fall. This, combined with the dense canopy of leaves created by L. maackii, results in distinguishable patches of green among other species that lack leaves at these times. Therefore, aerial photography taken in early spring or late fall should clearly depict areas of L. maackii presence. The Louisville/Jefferson County Information Consortium (LOJIC) is a conglomerate of various local agencies that have joined together to meet the 
GIS needs of the Louisville area. One service provided by LOJIC is the capturing of a high resolution aerial image of the entire metro area every few years. These raster images are taken in early spring, a time that allows L. maackii presence to be identified as lone patches of green vegetation.

The first step in mapping L. maackii invasion adjacent to streams in the Beargrass Creek watersheds was to isolate the fourteen digit Hydrologic Unit Codes (HUC 14) that drain into the three branches of Beargrass Creek. These were identified as the Muddy Fork, Middle Fork, Beargrass Creek, and South Fork. These polygons were selected and made into a separate shapefile. A subset of the LOJIC 2006 hydrographic polygon shapefile (rivers, streams, and creeks) was then selected, clipped to Beargrass Creek watersheds, and buffered to $15 \mathrm{~m}$ in order to represent the riparian area.

The next step was to create a new polyline shapefile that identified L. maackii presence or absence within 15m of the edge of the creek based on the LOJIC 2009 aerial photograph. Although sophisticated techniques associated with remote sensing have been developed in order to identify L. maackii with precise accuracy (Shouse et al. 2012), these methods were not necessary for our purposes. Rather, segments of the stream that contained clearly distinguishable patches of green within the $15 \mathrm{~m}$ buffer were identified as L. maackii present, and those without were identified as L maackii absent (Fig. 1-1). The total lengths of stream segments adjacent to L. maackii were then used to calculate percent invasion within each HUC 14 watershed and within all of the Beargrass Creek watersheds combined. Segments of creek within Cherokee and Seneca Parks were assigned an invasion status based on knowledge of recent restoration efforts. A LOJIC landuse polygon was also clipped to the Beargrass Creek watersheds polygon (Fig. 1-2). 
Ground truthing was performed in order to estimate the accuracy of this technique. This was accomplished by choosing 20 points along Beargrass Creek and confirming whether the presence/absence invasion status was accurately identified by physically visiting those points. The points were haphazardly chosen and were relatively evenly dispersed throughout the four watersheds. Percent accuracy was then calculated based on the number of accurate identifications from the total number of points visited.

The results of this GIS study showed variable invasion among the Beargrass Creek watersheds, ranging from 28\% (Middle Fork) to 100\% (Beargrass Creek) (Fig. 13). Overall, about $43 \mathrm{~km}$ out of a total $84 \mathrm{~km}$ (about 51\%) of Beargrass Creek were adjacent to L. maackii. Ground truthing of 20 points dispersed throughout the watersheds suggested an $85 \%$ accuracy of invasion mapping. Some inconsistencies between the ground truth and the map occurred due to relatively old images; the aerial photograph used in this study was from 2009 , which was 4 years prior to this study. The aerial image was taken prior to the majority of the L. maackii removal in the Olmstead parks. It is also possible that L. maackii invasion could have spread in some areas since the 2009 photograph was taken. During groundtruthing I also found evidence of some restoration efforts that were previously unknown to me. Additionally, I found that my estimate of $L$. maackii invasion was relatively conservative based on personal observation of the riparian area as I was visiting the points.

Lonicera maackii can potentially impact stream ecology directly and indirectly. These measures of invasion extent could help predict differential effects of L. maackii on the aquatic communities throughout the Beargrass Creek watersheds. Furthermore, the map of $L$. maackii invasion within the watersheds can pinpoint areas of greatest concern. 
Based on this map (Fig. 1-1), the levels of concern regarding influences of L. maackii invasion are not uniform across all areas of Beargrass Creek. For instance, Muddy Fork seems to have both a high percentage of invaded stream and also a high total length of invaded stream (Fig 1-3). Coincidentally, large portions of this fork also pass through parks, cemeteries, etc (Fig. 1-2). From a management perspective, these segments would likely be easier to restore as opposed to Beargrass Creek watershed, which has mainly residential and industrial land use (Fig. 1-2). Several other areas, including some of the western segments of South Fork Beargrass Creek, are also heavily invaded and run through parks, cemetaries, etc. Use of these maps (Figs 1-1,1-2) could help inform decisions about restoration efforts to reduce the influence of $L$. maackii on aquatic ecosystem processes and invertebrate communities throughout the Beargrass Creek watersheds in Jefferson County, KY. 


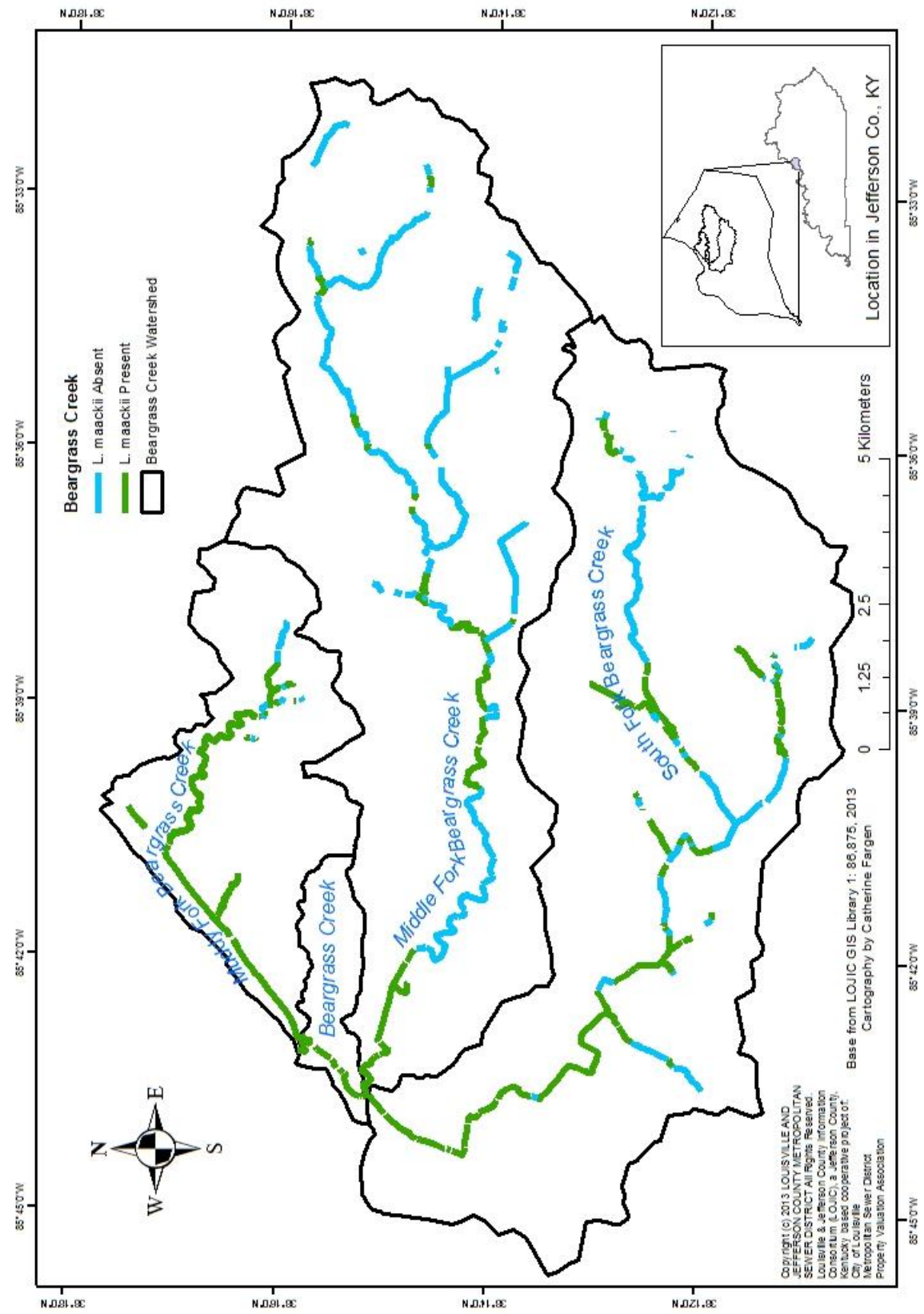

Figure 1-1. Map of Beargrass Creek Watersheds and areas of Beargrass Creek adjacent to riparian $L$. maackii invasion 


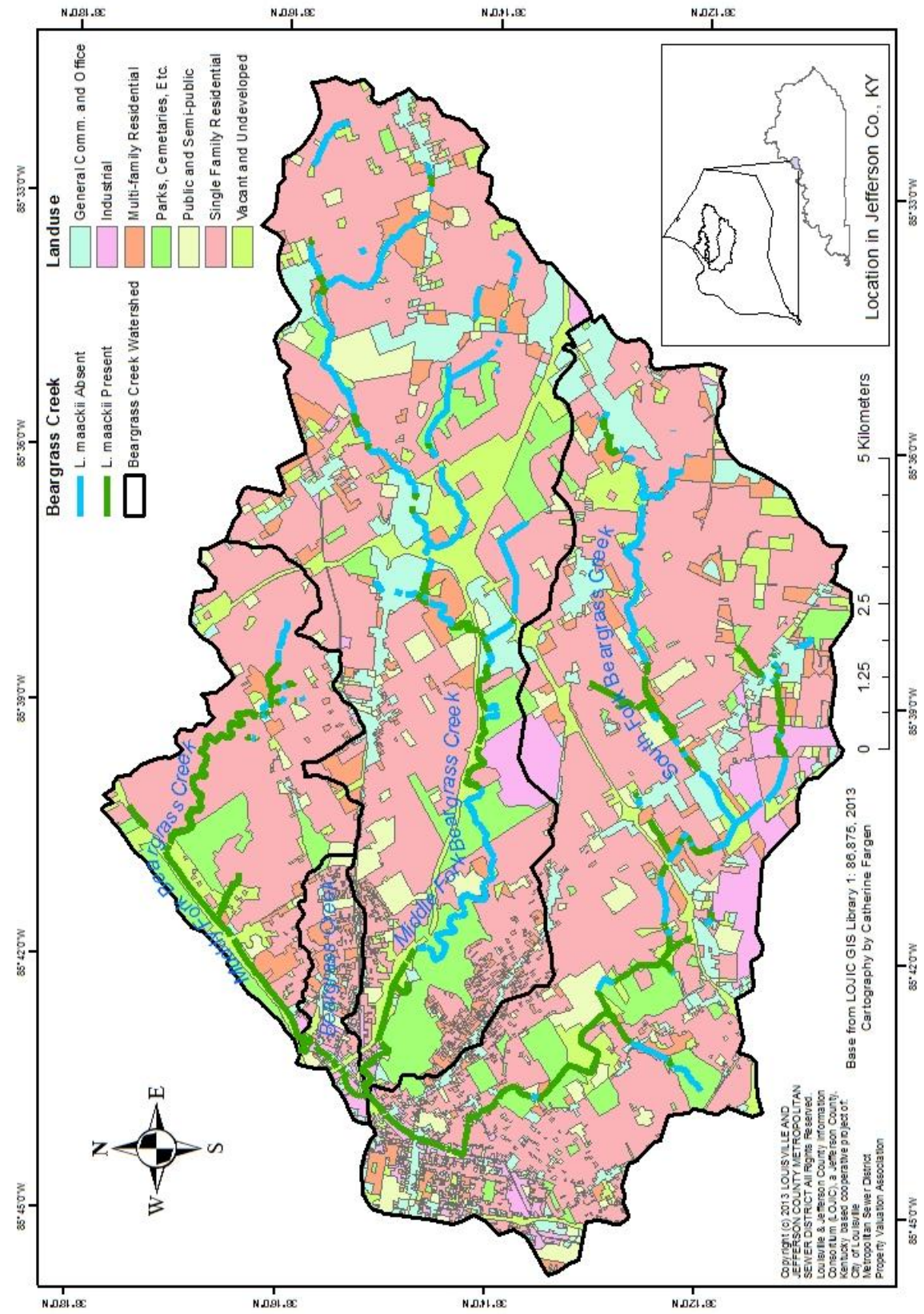

Figure 1-2. Map of Beargrass Creek Watersheds and areas of Beargrass Creek adjacent to riparian L. maackii invasion including land use 


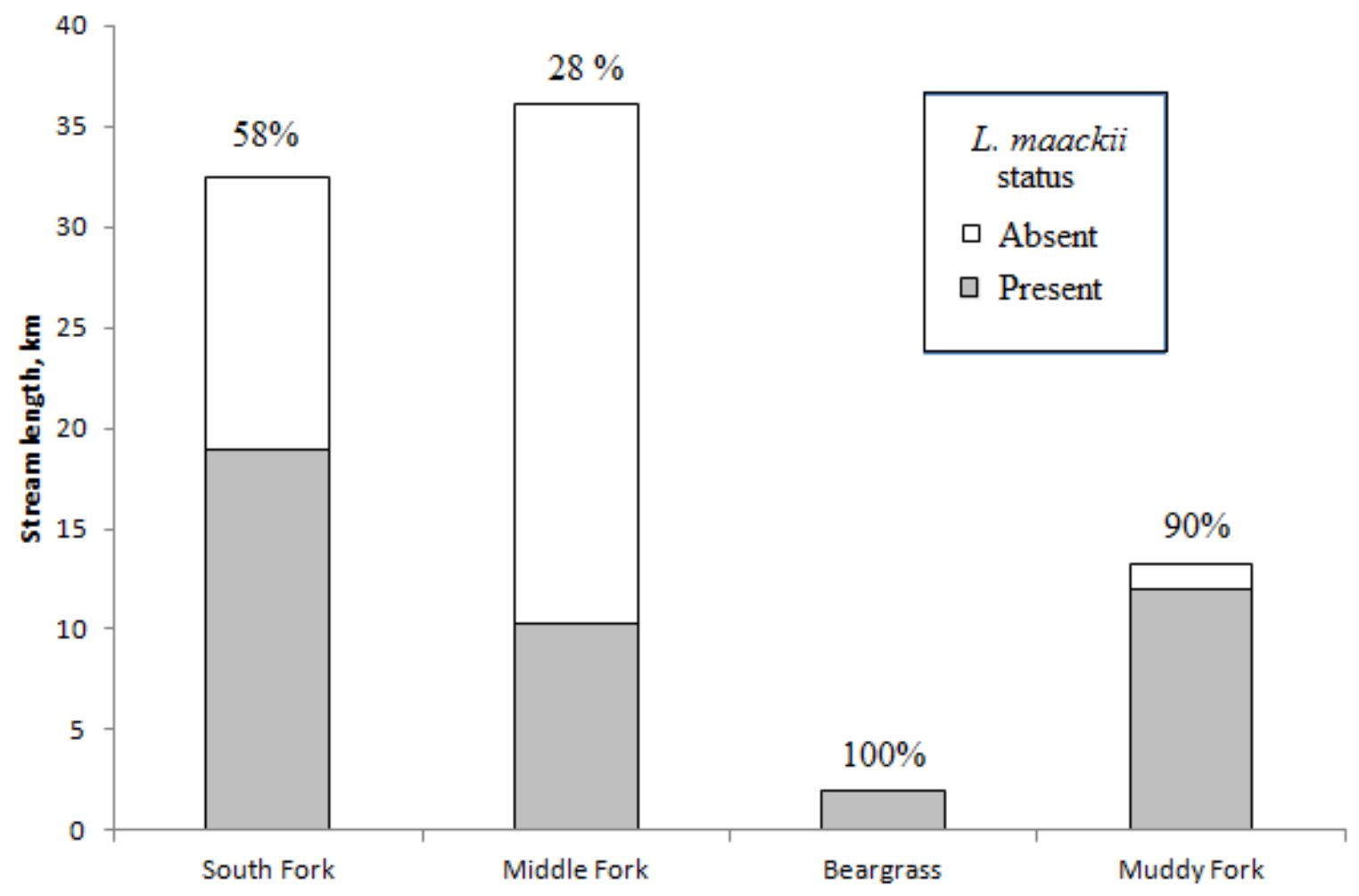

Figure 1-3. Total stream length and percentage breakdown of L. maackii invasion and absence in Beargrass Creek watersheds. 


\section{CHAPTER 2: THE INFLUENCE OF LONICERA MAACKII ON LEAF LITTER DECOMPOSITION AND MACROINVERTEBRATE COMMUNITIES IN AN URBAN STREAM}

\section{Introduction}

Leaf litter decomposition, the process by which fallen plant matter breaks down physically and chemically, is an extremely important ecosystem process. Allochthonous inputs, or the addition of fallen leaf matter from land to aquatic systems, form the base of foodwebs in low order streams (Vannote et al. 1980). Additionally, leaf litter decomposition is an integral step in the cycling of many nutrients such as carbon, nitrogen, and phosphorus (Lindeman 1942, Triska et al. 1984, Meyer \& Likens 1979).

The rate of leaf litter decomposition is controlled by many biotic and abiotic factors, many of which are well understood. For instance, the quality or chemical composition of leaves, as well as the community of organisms, such as macroinvertebrates, fungi, and bacteria, consuming the organic matter, will partially determine how quickly decomposition occurs (Melillo et al. 1982, Covich et al. 1999). Environmental variables such as temperature, light, water chemistry, dissolved oxygen, and physical disturbance can also alter the decay rate (Guo \& Sims 2001, Gulis \& Suberkropp 2003, Webster \& Benfield 1986, Gurtz, et al. 1988). Despite a good understanding of the role of individual factors on decomposition, the cumulative effects 
of multiple factors, especially those that change in response to anthropogenic influences, are not as well understood.

Invasive plants along streambanks, introduced and spread mostly through human behavior, represent a relative unknown in ecologists' understanding of stream ecology, despite a wealth of studies examining invasive plant impacts in terrestrial communities (Bailey et al. 2001, Reinhart \& VandeVoort 2006). Based on studies in terrestrial systems, invasive plants can be expected to directly affect leaf litter decomposition in a system. For instance, litter from invasive species often contains a different chemical composition than natives, resulting in altered decomposition rates between species. Godoy et al. (2010) investigated 19 co-familial native-invasive pairs and found overall slower terrestrial decomposition rates among leaf litter of invasive species. Some studies have shown no significant difference in the decomposition rates, but found altered nutrient retention between native and invasive plant litter (Hata et al. 2012). Several other studies have found increased decomposition rates in invasive litter. For example, Allison and Vitousek (2004) compared the decay rates of 5 native and 6 invasive understory plants in terrestrial plots and found wide variation, with invasives decomposing more quickly than natives.

Only a few studies that have examined effects of invasive species on aquatic decomposition rates have found similar effects. For example, Swan et al. (2008) compared in-stream decomposition rates of 6 native riparian tree species to that of the invasive tree of heaven (Ailanthus altissima) and found consistently faster decomposition from the invasive. An aquatic study in which litter from a native plant and invasive saltcedar (Tamarix ramossisima) were paired found faster leaf decomposition and lower 
abundance and diversity of macroinvertebrates associated with the saltcedar (Bailey et al. 2001).

Invasive plants can also alter decomposition rates and invertebrate communities indirectly by altering environmental factors such as light availability and habitat quality. Ashton et al. (2005) compared various native and invasive plant litter species in uninvaded plots and plots invaded by Alliaria petiolata (garlic mustard), Lonicera japonica (Japanese honeysuckle), Celastrus orbiculata (Asian bittersweet), Elaeagnus umbellate (autumn olive), and Rosa multiflora (multiflora rose). The study found faster terrestrial decomposition rates in invaded sites independent of plant litter type. The authors suggested that altered microbial communities and microclimates could drive differences. Another study in an aquatic environment showed some differences between saltcedar invaded versus uninvaded sites in leaf litter decomposition rates, which were thought to have resulted from altered aquatic invertebrate communities (Kennedy \& Hobbie 2004). Further, Read and Barmuta (1999) compared stream reaches invaded by willows (Salix spp) to native reaches and found altered benthic invertebrate communities due to altered light regimes, water chemistry, and patch quality.

One invasive plant that may have significant impacts on leaf litter decomposition dynamics in aquatic systems is Lonicera maackii (amur honeysuckle). L. maackii is an invasive exotic shrub of Asian origins which thrives in the Eastern United States. Originally planted as an ornamental and to aid in erosion control, this species aggressively spreads by a number of means, most notably through birds that carry the seeds after consuming the plant's abundant berries. The plant is characterized by dense vegetation up to $5 \mathrm{~m}$ tall and shallow yet extensive root structures (NPS 2013). 
Lonicera maackii has been studied for a number of years, and many of its effects on terrestrial systems are relatively well known. For instance, the plant is among the first to leaf out in the early spring and among the last to lose its leaves in the fall, resulting in a prolonged growing season. The early leaf expansion, late leaf abscission, and dense canopy formations result in increased competition for light and decreased reproductive abilities of nearby and understory plants of other species (Miller \& Gorchov 2004). Allelopathic chemicals in the leaf and root tissues of $L$. maackii have also been found to inhibit seed germination of native plants (Dorning \& Cipollini 2006). Relatively high nitrogen content leaves and rapid terrestrial decomposition rates of L. maackii in terrestrial systems can alter nutrient cycling dynamics (Blair \& Stowasser 2009). A study by Trammell et al. (2012) suggested that L. maackii inhibits foliar production since forests invaded by L. maackii produced significantly less leaf biomass than comparable uninvaded forests. This study also found increased decay rates and nitrogen release associated with L. maackii leaf litter as compared to Acer saccharum (sugar maple). Additionally, L. maackii can influence invertebrate communities; studies have shown that phenolic metabolites may deter damage from terrestrial insect herbivores (Cipollini et al. 2008).

Despite the longstanding efforts to understand terrestrial implications of L. maackii invasion, fewer studies have sought to determine the effects on aquatic ecosystems. Recently, however, ecologists have attempted to investigate these consequences. A study by Lewis and Brown (2010) compared leaf litter from L. maackii to that of 3 native species (sycamore (Platanus occidentalis), dogwood (Cornus florida), and redbud (Cercis canadensis)) in an invaded urban stream environment and found that L. maackii 
decomposed faster than the native species. McNeish et al. (2012) found faster in-stream L. maackii leaf litter decomposition rates and altered invertebrate communities compared to leaves of native ash (Fraxinus spp.) and sycamore, and mixed leaf packs. To date, no published studies have looked at both direct and indirect effects of this species on aquatic decomposition and associated macroinvertebrate communities. The purpose of this study is to evaluate the direct and indirect effects of L. maackii invasion by investigating decomposition rates of L. maackii and the native species Acer saccharum (sugar maple) in stream segments adjacent to areas of L. maackii invasion and in areas where the $L$. maackii has been removed for restoration purposes. We will address three specific questions: 1.) Do L. maackii and A. saccharum differ in their decomposition rates in stream ecosystems? 2.) Does L. maackii invasion of streambanks indirectly alter decomposition rates for both species? 3.) Do L. maackii and A. saccharum differ in their direct and indirect effects on macroinvertebrate communities?

\section{Methods}

\section{Study Site}

Beargrass Creek is a network of three converging waterways (South Fork, Middle Fork, and Muddy Fork) in Jefferson County, Kentucky that drains $160 \mathrm{~km}^{2}$ of surrounding watershed and empties into the Ohio River. This study took place in the Middle Fork of Beargrass Creek (38 $\left.14^{\prime} 14^{\prime \prime}, 85^{\circ} 39^{\prime} 53^{\prime \prime}\right)$, a $3^{\text {rd }}$ order stream with an average discharge of approximately $1.1 \mathrm{cms}$ (USGS 2013). The Middle Fork Beargrass Creek subwatershed passes through suburban and urban land, 33\% of which is impervious surface (Beargrass Creek Watershed Council 2005). Despite the fact that the 
stream also runs through a series of city parks and protected lands, this stream is highly symptomatic of urban stream syndrome. Portions of the streambank have been entirely paved, a Combined Sewage Overflow system frequently leaks contaminants into the waterway, and high levels of surrounding impervious surface create incised channels, frequent flash floods, and increased chemical runoff (Beargrass Creek Watershed Council 2005). Still, Middle Fork Beargrass Creek has a small but resilient community of aquatic invertebrates, fish, and plants, and the local human community and park organizations have been working over the past several years to restore the biodiversity of the creek and surrounding riparian zones.

In 2005, the Olmsted Parks Conservancy initiated a $\$ 3.5$ million project aimed at eliminating invasive species in several parks throughout Jefferson County. Since then, $L$. maackii, which established widely in Cherokee and Seneca Parks after the 1974 tornado, has been removed in about $98 \%$ of these two parks (Waltman pers. comm., 2013). To date, about $28 \%$ of Middle Fork Beargrass Creek remains invaded by L. maackii (Fig 12). At the start of this experiment, three segments of Middle Fork Beargrass Creek which run through $L$. maackii removal areas, as well as three nearby segments where L. maackii remains, were chosen in order to investigate the effects of L. maackii removal versus invasion (Fig. 2-1). Due to an early miscommunication with management, one of the initial L. maackii invaded sites had to later be reassigned as a L. maackii removal site, thus resulting in two invaded and four removal plots. All segments occurred in a $7 \mathrm{~km}$ stretch of stream. The native species, A. saccharum, was chosen to compare litter decomposition rates because it is also well represented in the study areas. 


\section{Experimental design}

This study was a reciprocal transplant experiment in which leaf litter from $L$. maackii and native A. saccharum was collected soon after senescence in Fall 2011 and air dried for 3-8 weeks. Leaf packs were then made by weighing $5.00 \pm 0.05$ grams of leaf litter from a single species and placing them in $5 \mathrm{~mm}$ mesh bags $(24 \times 37 \mathrm{~cm})$. One hundred thirty-two bags of each species were prepared, or 264 bags total. Seven A. saccharum packs were tied to a nylon string and coupled with seven L. maackii packs to form each paired replicate. These replicates were then secured with zip ties to root bundles on the sides of the streambank in early January 2012. Two study sites in segments of the stream adjacent to $L$. maackii invasion as well as four sites where $L$. maackii had been removed were chosen, and each study site contained three paired replicates (Fig. 2-1). Additionally, 6 control bags of each species were carried throughout the process but were not incubated in the stream. The bags were then taken back to the lab for immediate processing to account for handling loss and air dry/ oven dry/ ashed mass conversions.

The differences in decomposition rates between $A$. saccharum and L. maackii were expected to be significant due to chemical and physical differences of the leaves (Trammell et al. 2012), so collection dates for each species followed a separate schedule. One bag of A. saccharum from each of 3 replicate strings at each site was collected 16, $49,75,112,140,181$, and 216 days after experiment initiation and one bag of $L$. maackii from each replicate string and each site was collected at days 3, 6, 10, 16, 26, 35, and 49. When collected, mesh bags were placed in plastic Zip lock bags, transported to the lab 
over ice, and stored at $4^{\circ} \mathrm{C}$ until ready to process. Additionally, environmental variables (light, temperature) were measured on one day to compare between-site conditions.

\section{Leaf litter decomposition}

In the lab, leaf litter was removed from mesh bags and gently rinsed over $4 \mathrm{~mm}$ and $121 \mu \mathrm{m}$ sieves. Material that was retained in the $4 \mathrm{~mm}$ sieve was placed in paper bags, oven dried at $60^{\circ} \mathrm{C}$ for 48 hours, cooled, and weighed in order to measure leaf mass loss on each sampling date. It was apparent upon collection that significant sediment infiltration had occurred in our samples, producing artificially high oven dry mass (ODM). Therefore, a subsample of each sample was then removed, weighed in an aluminum pan, combusted at $550^{\circ} \mathrm{C}$ for one hour, cooled in desiccators for 4 hours, and re-weighed. This was used to calculate the ash-free dry mass (AFDM) and standardize the percent organic mass loss at every interval to account for sediment deposition. Additionally, sediment samples were taken from the field sites and also dried at $60^{\circ} \mathrm{C}$ and $550^{\circ} \mathrm{C}$ to estimate the organic content in sediment. We then used a soil correction equation to isolate the fraction of organic content originating from leaf litter rather than sediment infiltration (Blair 1988).

\section{Macroinvertebrates}

Material that passed through the $4 \mathrm{~mm}$ sieve and was retained by the $121 \mu \mathrm{m}$ sieve was transferred to Whirl-paks® and stored in $70 \%$ ethanol. Once all collections were complete the material was transferred to petri dishes and sorted, and macroinvertebrates were identified under a dissecting microscope and archived in glass vials. Invertebrates 
were identified to family (or lowest reasonable taxon) and assigned to functional feeding groups (FFG) based on Merrit et al. (2008) and Thorp \& Covich (2001).

\section{Data Analysis}

The percent ODM remaining was plotted against time, and the exponential decay model was used to calculate the daily decomposition constants $(\mathrm{k})$ for each replicate (Peterson \& Cummins 1973). The percent AFDM remaining was also plotted against time and the corresponding $\mathrm{k}$ values were calculated to remove the influence of inorganic deposition. Two-way mixed-model analysis of variance (ANOVA) tests were then performed on the resulting ODM and AFDM k values using leaf litter species and stream invasion status as fixed factors and site as a random covariate.

Macroinvertebrate abundance per site (the 3 replicates were composited) per collection day was $\ln ($ abundance+1) transformed and analyzed using mixed-model ANOVA with time, stream invasion status, and leaf litter species as fixed factors and site as a random covariate. Morphotype richness and Shannon diversity were averaged between the three replicates (in order to account for one missing data point) per site per collection date and was also analyzed with a mixed-model ANOVA using time, stream invasion status, and leaf litter species as fixed factors and site as a random covariate. These dependent variables were also analyzed on day 49, the last day that both litter species were still present in litter bags, with litter species and invasion status as fixed factors and site as a random covariate. Additionally, FFGs were also averaged per site per collection day and analyzed across all days and on day 49 using the same methods. Bonferroni corrections were not considered in order to take a liberal interpretation of any possible effects on functional groups. For statistical interpretation, we used $\alpha=0.05$, and 
any p-value between 0.05 and 0.1 was considered marginally significant. Statistical analyses were performed using SYSTAT (Version 13).

\section{Results}

Lonicera maackii decomposed significantly faster than A. saccharum when either ODM or AFDM k values were used (Table 2-1, 2-2). On day 49 across all sites, 93.47\% AFDM was lost by L. maackii, compared to $68.27 \%$ AFMD by A. saccharum. Acer saccharum took 112 days to achieve $92.08 \%$ loss (Fig. 2-2). The daily decay coefficients, which represent the grams of leaf litter lost per gram of leaf litter present per day, ranged from 0.019 to 0.072 for A. saccharum litter and 0.038 to 0.095 for L. maackii litter (Table 2-1). The results of the two-way ANOVA suggested that the stream invasion status did not have a significantly detectable effect on mass loss (Table 2-2). Additionally, interactive effects between litter species and stream invasion status were not significant (Table 2-2).

Macroinvertebrate analyses for total abundance across all days were significant with respect to time and litter species effects (Table 2-3). Abundance increased over time and the cumulative total was ultimately $400 \%$ higher in $A$. saccharum compared to $L$. maackii (Fig. 2-3). Morphotype richness was significant with respect to time, and Shannon diversity index was marginally significant with respect to time (Table 2-3, Fig. 2-3), with diversity increasing as number of days progressed. On day 49, invertebrate abundance differed significantly by species (Table 2-4) with $43 \%$ higher abundance associated with A. saccharum (Fig. 2-3). 
Analysis of FFGs showed overall significant increases in predators and shredders over time and marginally significant increases in collector gatherers over time irrespective of litter species (Table 2-5). On day 49, analysis of FFGs showed higher abundances of predators and scraper-gatherers associated with A. saccharum (177\% and $172 \%$ greater, respectively) compared to L. maackii litter (Table 2-6). Predators also showed a significant stream invasion status effect on day 49 (108\% greater across both litter species) and a marginally significant invasion status $\mathrm{x}$ litter species effect, with greater numbers of predators associated with $L$. maackii invaded plots, especially in the A. saccharum litter (Fig 2-4). The average number of individuals in each FFG for each treatment across all days and on day 49 was also calculated (Fig 2-5). From this, we determined that collector gatherers were the most abundant FFG in A. saccharum litter across all days, accounting for about $56 \%$ of all individuals. In L. maackii litter, shredders were the most abundant across all days, accounting for about $66 \%$ of all individuals. On day 49, shredders were the most well represented FFG, accounting for 69\% of all individuals in A. saccharum litter and 65\% of individuals in L. maackii litter.

\section{Discussion}

This study showed that L. maackii litter decomposed approximately twice as quickly as A. saccharum litter, with mean residence times (1/k) of 19.45 and 39.04 days, respectively. This trend is consistent with similar studies that found invasive L. maackii decomposed more quickly in aquatic environments than its various native counterparts (Lewis \& Brown 2010, McNeish et al. 2012). This is unsurprising since the rate of decay between species depends largely on litter quality, and L. maackii is known to have a higher nitrogen content than A. saccharum (Trammell et al. 2012). 
We found no evidence that streambank invasion by L. maackii affected decomposition. Acer saccharum decomposed slightly slower in areas of L. maackii invasion, with a mean residence time of 42.1 days in invaded sites as opposed to 36.0 days in removal sites, and L. maackii decomposed slightly faster in areas of invasion, with mean residence times of 19.2 and 19.7 days in invaded and removal sites. However, these differences were not statistically significant. To our knowledge, no prior studies to investigate the effects of L. maackii invasion in adjacent riparian areas on aquatic leaf litter decomposition rates have been published. However, we expected that in aquatic systems, L. maackii could indirectly alter decomposition rates by altering the biotic and abiotic environment. For instance, replacement of native trees with L. maackii, a low and overhanging shrub, could influence stream shading, altering both light and temperature. In general, decomposition is often slowed in cooler, shadier streams (Lagrue et al. 2011). These effects could have been undetectable due to the season in which our study was performed, since L. maackii had finished decomposing by mid-February, when leaves on L. maackii bushes were not present. However, light and temperature measurements taken in June were still not found to significantly differ between treatments or sites. Lonicera maackii is also known to be allelopathic and has been found to influence aquatic insect species (Going \& Dudley 2008), which in turn could alter organic matter processing (Covich et al. 1999).

Our results are inconsistent with terrestrial studies in which L. maackii-invaded environments influenced decomposition rates for multiple species of leaf litter in terrestrial environments. Trammell et al. (2012) found small but detectably faster differences in A. saccharum decomposition in the presence of L. maackii invasion, and 
Arthur et al. (2012) found slower decomposition rates of both native and invasive litter in L. maackii invaded environments. Trammell et al. (2012) cited potential influences on microclimate, soil chemistry, and decomposer communities, as well as possible confounding landscape-scale factors such as nitrogen deposition and the urban heat island effect, as reasonable factors in their particular study. Arthur et al. (2012) attributed the effects to changes in microbial communities and potential changes in soil moisture.

In this study, we found that overall abundance of macroinvertebrates increased with time, possibly due to extended colonization periods and changes in seasonal weather (Pond et al. 2003). Acer saccharum leaf litter decomposed more slowly than L. maackii, so A. saccharum supported higher macroinvertebrate abundances than L. maackii. However, there were litter species effects irrespective of time as well, with higher abundances of macroinvertebrates on A. saccharum across all dates and on day 49, when both litter species could be simultaneously compared. Morphotype richness and Shannon diversity of invertebrates increased with time across all dates, with diversity increasing as the in-stream incubation period progressed. This was most likely due to increases in Chironomidae and Oligochaeta (collector-gatherers), Asellidae (shredders), and Planariidae (predators); these four taxa were by far the most widely represented invertebrates found in this study (Appendix A). The FFGs associated with these taxa were also found to increase with time (Table 2-5). On day 49, higher abundance of predators and scraper gatherers were supported in A. saccharum versus L. maackii litter (Table 2-6). Primary consumers were likely deterred by phytotoxic chemicals from $L$. maackii (Cipollini et al. 2008), which would also deter higher trophic levels in L. maackii litter. Furthermore, the higher abundances of predators were found in L. maackii invaded 
sites, especially on A. saccharum litter (Fig. 2-4). Although the exact mechanisms of this observation are uncertain, it is notable that the predators were dominated by Planariidae (flatworms), which unlike many aquatic invertebrates, do not experience a terrestrial life stage. Therefore, these individuals could potentially be less impacted by indirect effects of terrestrial invasion of L. maackii along the streambank.

Overall, collector gatherers represented the greatest proportion of individuals found on A. saccharum litter, constituting $54 \%$ and $59 \%$ of the total community abundance in invaded and removal sites, respectively. Shredders represented the second highest proportion of invertebrates in these site categories, with $41 \%$ and $39 \%$ respectively. In L. maackii litter, shredders were the most abundant (61\% and $72 \%$ in invaded and removal plots), and collector gatherers were the second most abundant (37\% and $27 \%$ ). On day 49, shredders constituted the highest proportion of individuals in each treatment; in A. saccharum shredders accounted for $59 \%$ and $81 \%$ of the total community numbers in invaded and removal plots, respectively, and in L. maackii they accounted for $62 \%$ and $68 \%$. Collector gatherers were the second most abundant FFG across these treatments (Fig. 2-5). These data are contrary to a similar study, which found higher densities of macroinvertebrates, especially collector gatherers, on L. maackii rather than native leaf litter (McNeish et al. 2012). The causes of these inconsistencies are indefinite. However, a few differences between study sites could offer some explanation. The stream in our study, located near suburban development, was highly polluted with combined sewer effluent and affected by rapid runoff events typical of urban stream syndrome (Beargrass Creek Watershed Council 2005), which could potentially influence macroinvertebrate communities (Cuffney et al. 2010). The extent of urban stream 
syndrome in the McNeish (2012) study stream is unclear. Our invertebrate community assemblages were also different; although our study had 10 out of the same 14 invertebrate morphotypes found in the McNeish (2012) study in common, we also found 21 additional morphotypes that were not present in the other study.

The lack of detectable indirect effects (effects of stream invasion status) in our study may be due to an overriding factor: urbanization. Urbanization influences hydrologic regimes and water chemistry in a number of ways. Increased impervious surface can lead to increased surface runoff and decreased evapotranspiration of plants, which alters streamflow patterns by increasing frequency of high flow and altering base flow/storm flow dynamics (Konrad \& Booth 2005). This, in turn, alters biological communities by decreasing suitable habitat (Konrad \& Booth 2005). Higher nutrients in urban streams can increase microbial activity (Imberger et al. 2008), but pollution such as pavement sealant runoff can decrease invertebrate abundance and alter community assemblages (Bryer et al. 2010). A study by Chadwick et al. (2006) attempted to identify and quantify the biological, physical, and chemical effects of urbanization on ecosystem processes such as litter decomposition. The study concluded that effects of urbanization due to impervious surface, such as altered flow regimes and invertebrate biodiversity, can influence leaf litter decay rates depending on local characteristics and interactive effects between attributes.

Additionally, differences between L. maackii invaded versus restored stream reaches could be undetectable due to legacy effects remaining even after the shrub had been removed. For example, one study investigated the effects of invasive tree, especially Acacia spp., removal in riparian zones on aquatic macroinvertebrate 
communities. The removal sites were more similar to the pristine than the invaded sites, but some evidence of legacy effects existed (Samways et al. 2011).

\section{Conclusion}

Leaf litter decomposition is an essential ecosystem process that is responsible for supporting stream ecosystems and cycling nutrients, and changes in decomposition rates could have longstanding impacts throughout the rest of the aquatic food web. For instance, leaf litter that falls into a stream typically supports the ecosystem throughout the winter months. However, if the rate of decomposition is increased such that organic matter leaves the system twice as quickly usual in a system, as found in our study, then fewer resources could be available to invertebrates and subsequent trophic levels in the spring. Findings from our study show that L. maackii litter reduces the abundance of macroinvertebrates, in part due to its rapidly decaying litter. Streambanks densely colonized by this invasive shrub would likely reduce macroinvertebrate abundance and alter FFGs along these reaches; this trend was detectable, even in a highly disturbed, urban stream. Anthropogenic influences such as increased impervious surface, increased nutrient inputs, and decreased riparian buffer zones have significantly influenced the leaf litter decomposition and associated invertebrate communities in stream ecosystems (Chadwick et al. 2006, Gulis \& Suberkropp 2003, Kreutzweiser et al. 2010), and the introduction of invasive species is no exception to this rule. 
Table 2-1. K-values based on corrected AFDM data

\begin{tabular}{|c|c|c|c|}
\hline Site & $\begin{array}{c}\text { Stream } \\
\text { Invasion } \\
\text { Status }\end{array}$ & $\begin{array}{c}\text { Acer saccharum, average } \\
\text { from day 0-112 }\end{array}$ & $\begin{array}{c}\text { Lonicera maackii, average } \\
\text { from day 0-49 }\end{array}$ \\
\hline 1 & Invaded & 0.044219 & 0.064924 \\
\hline 2 & Removal & 0.028775 & 0.095351 \\
\hline 3 & Removal & 0.024311 & 0.044981 \\
\hline 4 & Removal & 0.072189 & 0.06749 \\
\hline 5 & Removal & 0.027517 & 0.055252 \\
\hline 6 & Invaded & 0.018653 & 0.038444 \\
\hline
\end{tabular}


Table 2-2. ANOVA table, F-statistics and p-values for ODM and AFDM. Significant factors $(p<0.05)$ are in bold

\begin{tabular}{|c|c|c|c|c|c|c|}
\hline & \multicolumn{3}{|c|}{ Oven Dry Mass (ODM) k } & \multicolumn{3}{c|}{$\begin{array}{c}\text { Ash-Free Dry Mass } \\
\text { (AFDM) k }\end{array}$} \\
\hline & $\mathbf{d f}$ & $\mathbf{F}$ & $\mathbf{p}$ & $\mathbf{d f}$ & $\mathbf{F}$ & $\mathbf{p}$ \\
\hline Litter species & $\mathbf{1}$ & $\mathbf{7 . 2 2 7}$ & $\mathbf{0 . 0 1 2}$ & $\mathbf{1}$ & $\mathbf{8 . 7 6 5}$ & $\mathbf{0 . 0 0 6}$ \\
\hline Invasion status & 1 & 0.381 & 0.570 & 1 & 0.494 & 0.521 \\
\hline site & 4 & 1.144 & 0.253 & 4 & 0.988 & 0.323 \\
\hline Invasion status x litter species & 1 & 1.874 & 0.182 & 1 & 0.206 & 0.654 \\
\hline
\end{tabular}


Table 2-3. Statistics for abundance, morphotype richness, and Shannon diversity across all dates. Significant factors $(\mathrm{p}<0.05)$ are in bold.

\begin{tabular}{|c|c|c|c|c|c|c|c|c|c|}
\hline & \multicolumn{2}{|c|}{ In(Abundance) } & \multicolumn{3}{c|}{$\begin{array}{c}\text { Morphotype } \\
\text { Richness }\end{array}$} & \multicolumn{3}{c|}{$\begin{array}{c}\text { Shannon } \\
\text { Diversity }\end{array}$} \\
\hline & df & $\mathbf{F}$ & $\mathbf{p}$ & $\mathbf{d f}$ & $\mathbf{F}$ & $\mathbf{p}$ & $\mathbf{d f}$ & $\mathbf{F}$ & $\mathbf{p}$ \\
\hline Time & $\mathbf{1}$ & $\mathbf{2 9 . 0 2 9}$ & $<\mathbf{0 . 0 0 1}$ & $\mathbf{1}$ & $\mathbf{3 0 . 8 7 6}$ & $<\mathbf{0 . 0 0 1}$ & 1 & 4.242 & 0.053 \\
\hline $\begin{array}{c}\text { Litter species } \\
\text { Invasion } \\
\text { status }\end{array}$ & $\mathbf{1}$ & $\mathbf{5 . 5 6 1}$ & $\mathbf{0 . 0 2 9}$ & $\mathbf{1}$ & 1.805 & 0.194 & 1 & 1.643 & 0.215 \\
\hline $\begin{array}{c}\text { Site } \\
\text { Invasion } \\
\text { status x litter } \\
\text { species }\end{array}$ & 1 & 0.146 & 0.712 & 1 & 0.097 & 0.760 & 1 & 0.288 & 0.605 \\
\hline $\begin{array}{c}\text { Invasion } \\
\text { status x time }\end{array}$ & 1 & 0.315 & 0.581 & 1 & 0.001 & 0.974 & 1 & 0.615 & 0.442 \\
\hline $\begin{array}{c}\text { Litter species } \\
\text { x time }\end{array}$ & $\mathbf{1}$ & $\mathbf{7 . 9 4 5}$ & $\mathbf{0 . 0 1 1}$ & 1 & 0.162 & 0.692 & 1 & 0.312 & 0.583 \\
\hline $\begin{array}{c}\text { Invasion } \\
\text { status x litter } \\
\text { species x time }\end{array}$ & 1 & 0.026 & 0.874 & 1 & 0.088 & 0.770 & 1 & 0.363 & 0.553 \\
\hline
\end{tabular}


Table 2-4. Statistics for abundance, morphotype richness, and Shannon diversity on day 49. Significant factors $(\mathrm{p}<0.05)$ are in bold.

\begin{tabular}{|c|c|c|c|c|c|c|c|c|c|}
\hline & \multicolumn{3}{|c|}{ In(Abundance) } & \multicolumn{3}{c|}{$\begin{array}{c}\text { Morphotype } \\
\text { Richness }\end{array}$} & \multicolumn{3}{c|}{ Shannon Diversity } \\
& df & $\mathbf{F}$ & $\mathbf{p}$ & $\mathbf{d f}$ & $\mathbf{F}$ & $\mathbf{p}$ & $\mathbf{d f}$ & $\mathbf{F}$ & $\mathbf{p}$ \\
\hline Litter species & $\mathbf{1}$ & $\mathbf{2 2 . 2 8 1}$ & $\mathbf{0 . 0 0 9}$ & 1 & 2.439 & 0.193 & 1 & 1.822 & 0.248 \\
\hline Invasion status & 1 & 0.195 & 0.681 & 1 & 1.754 & 0.256 & 1 & 1.538 & 0.283 \\
\hline site & 4 & 1.366 & 0.172 & 4 & & & 4 & 1.183 & 0.237 \\
\hline $\begin{array}{l}\text { Invasion status } \\
\text { x litter species }\end{array}$ & 1 & 0.419 & 0.553 & 1 & 0.011 & 0.922 & 1 & 2.212 & 0.211 \\
\hline
\end{tabular}


Table 2-5. Statistics for Functional Feeding Groups across all dates. Significant factors $(\mathrm{p}<0.05)$ are in bold.

\begin{tabular}{|c|c|c|c|c|c|c|c|c|c|}
\hline & $=$ & 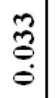 & $\frac{\circ}{\circ}$ & $\begin{array}{l}\infty \\
\infty \\
1 \\
0\end{array}$ & $\mid \begin{array}{l}n \\
0 \\
n \\
0 \\
0\end{array}$ & $\begin{array}{l}1 \\
1 \\
0\end{array}$ & $\begin{array}{l}n \\
0 \\
0 \\
0 \\
0\end{array}$ & $\begin{array}{l}\text { ते } \\
\text { İ }\end{array}$ & $\begin{array}{l}\dot{\partial} \\
\infty \\
0\end{array}$ \\
\hline $\mid \begin{array}{l}T \\
\vec{\Omega}\end{array}$ & {$\left[E_{1}\right.$} & 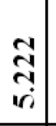 & $\begin{array}{l}\infty \\
\infty \\
\stackrel{-}{\llcorner} \\
\end{array}$ & $\begin{array}{l}\infty \\
0 \\
0 \\
0\end{array}$ & \begin{tabular}{|l|l}
$\infty$ \\
0 \\
$\vdots$ \\
0 \\
0
\end{tabular} & $\begin{array}{l}0 \\
\stackrel{0}{0} \\
0 \\
0\end{array}$ & $\begin{array}{l}8 \\
0 \\
0 \\
0\end{array}$ & 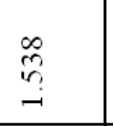 & $\begin{array}{l}8 \\
: \\
0 \\
\end{array}$ \\
\hline & $\Xi$ & -1 & - & - & + & - & - & - & - \\
\hline \multirow{3}{*}{ S } & $=$ & $\begin{array}{c}0 \\
\stackrel{2}{0} \\
\\
0\end{array}$ & $\begin{array}{l}\frac{1}{I} \\
\stackrel{5}{0}\end{array}$ & $\begin{array}{l}\circ \\
\stackrel{0}{\infty} \\
0\end{array}$ & $\mid \begin{array}{l}1 \\
n \\
n \\
0\end{array}$ & $\begin{array}{l}\infty \\
0 \\
0\end{array}$ & $\begin{array}{l}\infty \\
\stackrel{0}{0} \\
+ \\
0\end{array}$ & $\stackrel{n}{2}$ & $\begin{array}{l}\hat{n} \\
\hat{n} \\
0\end{array}$ \\
\hline & Ex & $\left|\begin{array}{c}\infty \\
\stackrel{2}{+} \\
\text { ii }\end{array}\right|$ & $\begin{array}{l}\exists \\
\overrightarrow{0}\end{array}$ & $\begin{array}{l}\mathscr{6} \\
8 \\
0\end{array}$ & \begin{tabular}{|l|l}
0 \\
$\hat{0}$ \\
0 \\
0
\end{tabular} & $\begin{array}{l}0 \\
\qquad \\
i \\
0 \\
0\end{array}$ & 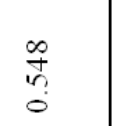 & 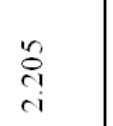 & $\begin{array}{l}n \\
7 \\
0\end{array}$ \\
\hline & $\Xi$ & -1 & - & - & + & - & - & - & - \\
\hline \multirow{3}{*}{ a } & $=$ & $\begin{array}{l}0 \\
\mathscr{0} \\
\dot{0}\end{array}$ & $\begin{array}{l}n \\
\infty \\
0 \\
0\end{array}$ & $\begin{array}{l}0 \\
\stackrel{0}{0} \\
0 \\
0\end{array}$ & $\begin{array}{c}1 \\
n \\
n \\
0 \\
\end{array}$ & 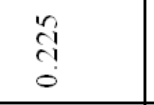 & $\begin{array}{l}\hat{8} \\
0 \\
0\end{array}$ & $\underset{0}{\Xi}$ & $\underset{0}{\exists}$ \\
\hline & Ex & $\begin{array}{c}7 \\
7 \\
i \\
\square\end{array}$ & $\begin{array}{l}\hat{m} \\
\stackrel{0}{0}\end{array}$ & ণิ & $\mid \begin{array}{l}n \\
2 \\
0 \\
0\end{array}$ & $\begin{array}{l}\text { Oे } \\
\text { ? } \\
-1\end{array}$ & $\begin{array}{l}0 \\
\infty \\
\infty \\
m\end{array}$ & $\stackrel{\vec{c}}{i}$ & $\begin{array}{c}\hat{n} \\
\hat{n} \\
c \\
c\end{array}$ \\
\hline & $\Xi$ & -1 & - & - & + & - & $\neg$ & - & - \\
\hline \multirow{3}{*}{ Uِ } & $=$ & $\left|\begin{array}{l}\infty \\
0 \\
0 \\
0\end{array}\right|$ & $\begin{array}{l}\hat{\sigma} \\
\text { है }\end{array}$ & $\begin{array}{l}+ \\
\infty \\
0 \\
0\end{array}$ & $\mid \begin{array}{l}\vec{t} \\
\vec{T} \\
0\end{array}$ & $\begin{array}{l}\stackrel{\partial}{\hat{\alpha}} \\
0\end{array}$ & $\begin{array}{l}\vec{\infty} \\
\infty \\
0 \\
0\end{array}$ & $\begin{array}{l}\overrightarrow{5} \\
\stackrel{5}{0}\end{array}$ & $\begin{array}{l}\stackrel{0}{0} \\
\infty \\
0\end{array}$ \\
\hline & Ex & \begin{tabular}{|l|} 
\\
0 \\
0 \\
$m$
\end{tabular} & $\begin{array}{l}\infty \\
\infty \\
i ! \\
0\end{array}$ & $\begin{array}{l}0 \\
\stackrel{0}{0} \\
0\end{array}$ & $\mid \begin{array}{c}\vec{n} \\
\hat{n} \\
0\end{array}$ & $\begin{array}{l}0 \\
8 \\
0 \\
0\end{array}$ & $\begin{array}{l}\hat{\imath} \\
\hat{o} \\
0\end{array}$ & $\begin{array}{l}\text { 吕 } \\
\text { in }\end{array}$ & है \\
\hline & $\Xi$ & -1 & - & - & + & - & - & - & - \\
\hline \multirow{4}{*}{ 己 } & $\approx$ & 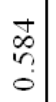 & ầ & $\begin{array}{l}0 \\
+1 \\
1 \\
0\end{array}$ & & $\begin{array}{l}\text { İ } \\
\stackrel{y}{0} \\
0\end{array}$ & $\begin{array}{l}\hat{\sigma} \\
\hat{0} \\
0\end{array}$ & $\begin{array}{l}0 \\
+ \\
0 \\
0\end{array}$ & $\begin{array}{l}\stackrel{\partial}{\circ} \\
0 \\
0\end{array}$ \\
\hline & Ex & $\mid \begin{array}{l}0 \\
0 \\
0 \\
0\end{array}$ & 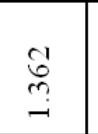 & $\begin{array}{l}\text { के } \\
\text { ?ִ } \\
0\end{array}$ & & $\begin{array}{l}\frac{n}{6} \\
0 \\
0\end{array}$ & 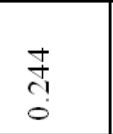 & $\begin{array}{l}0 \\
8 \\
0 \\
0\end{array}$ & $\overrightarrow{0}$ \\
\hline & $=4$ & -1 & -1 & - & & -1 & $\neg$ & - & - \\
\hline & & 音 & 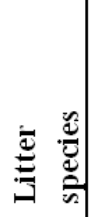 & 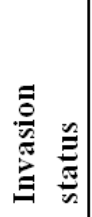 & 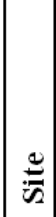 & 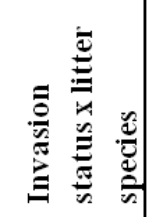 & 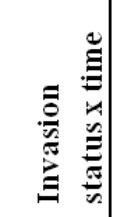 & 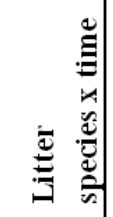 & 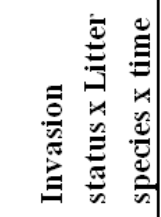 \\
\hline
\end{tabular}


Table 2-6. Statistics for Functional Feeding Groups, Day 49. Significant factors $(\mathrm{p}<0.05)$ are in bold.

\begin{tabular}{|c|c|c|c|c|c|}
\hline & $=$ & 总 & \begin{tabular}{|l|}
$\vec{S}$ \\
\\
0
\end{tabular} & $\mid \begin{array}{l}\mid \vec{a} \\
\grave{c}\end{array}$ & $\begin{array}{l}n \\
\stackrel{2}{2} \\
0\end{array}$ \\
\hline & $=$ & 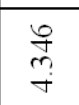 & \begin{tabular}{|l|}
$\infty$ \\
0 \\
0 \\
0
\end{tabular} & 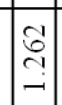 & 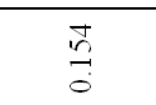 \\
\hline & $\exists$ & - & - & 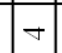 & $\tau$ \\
\hline \multirow{3}{*}{ 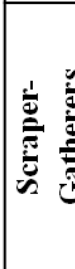 } & $=$ & 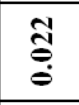 & 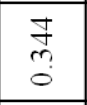 & 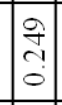 & 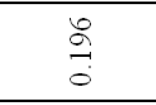 \\
\hline & 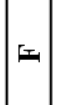 & 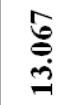 & $\underset{J}{\stackrel{g}{\exists}}$ & 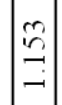 & 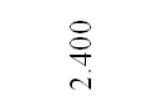 \\
\hline & $\exists$ & - & -7 & - & - \\
\hline & $=$ & $\stackrel{m}{\stackrel{m}{s}}$ & 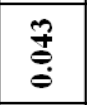 & 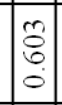 & $\begin{array}{l}0 \\
\stackrel{8}{\circ} \\
\stackrel{8}{\circ}\end{array}$ \\
\hline & $=$ & 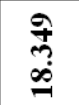 & $\begin{array}{l}0 \\
0 \\
0 \\
\infty \\
\infty\end{array}$ & $|\vec{r}|$ & $\frac{m}{f}$ \\
\hline & $\Xi$ & - & - & $\nabla$ & - \\
\hline \multirow{3}{*}{ 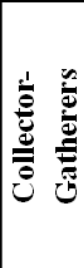 } & $=$ & $\begin{array}{l}\text { It } \\
\text { î̀ } \\
0\end{array}$ & $\begin{array}{l}\vec{\sigma} \\
\text { हे }\end{array}$ & $\mid$ & $\begin{array}{l}\stackrel{\infty}{7} \\
\stackrel{7}{0}\end{array}$ \\
\hline & 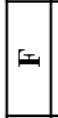 & $\stackrel{2}{2}$ & $\begin{array}{l}\tilde{a} \\
\tilde{\sigma}\end{array}$ & 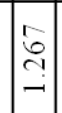 & 呑 \\
\hline & $\exists$ & - & - & $\nabla$ & - \\
\hline \multirow{4}{*}{ 竞 } & $=$ & $\begin{array}{ll}\frac{m}{3} \\
3 \\
\end{array}$ & \begin{tabular}{|l} 
\\
\\
0 \\
\end{tabular} & & $\begin{array}{l}\text { for } \\
\text { c. } \\
0\end{array}$ \\
\hline & D & $\begin{array}{l}\frac{J}{n} \\
\hat{n}\end{array}$ & $\begin{array}{l}\frac{1}{3} \\
\text { ma }\end{array}$ & & $\stackrel{5}{=}$ \\
\hline & $\Xi$ & - & - & 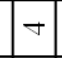 & - \\
\hline & & & 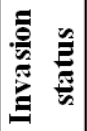 & & \\
\hline
\end{tabular}




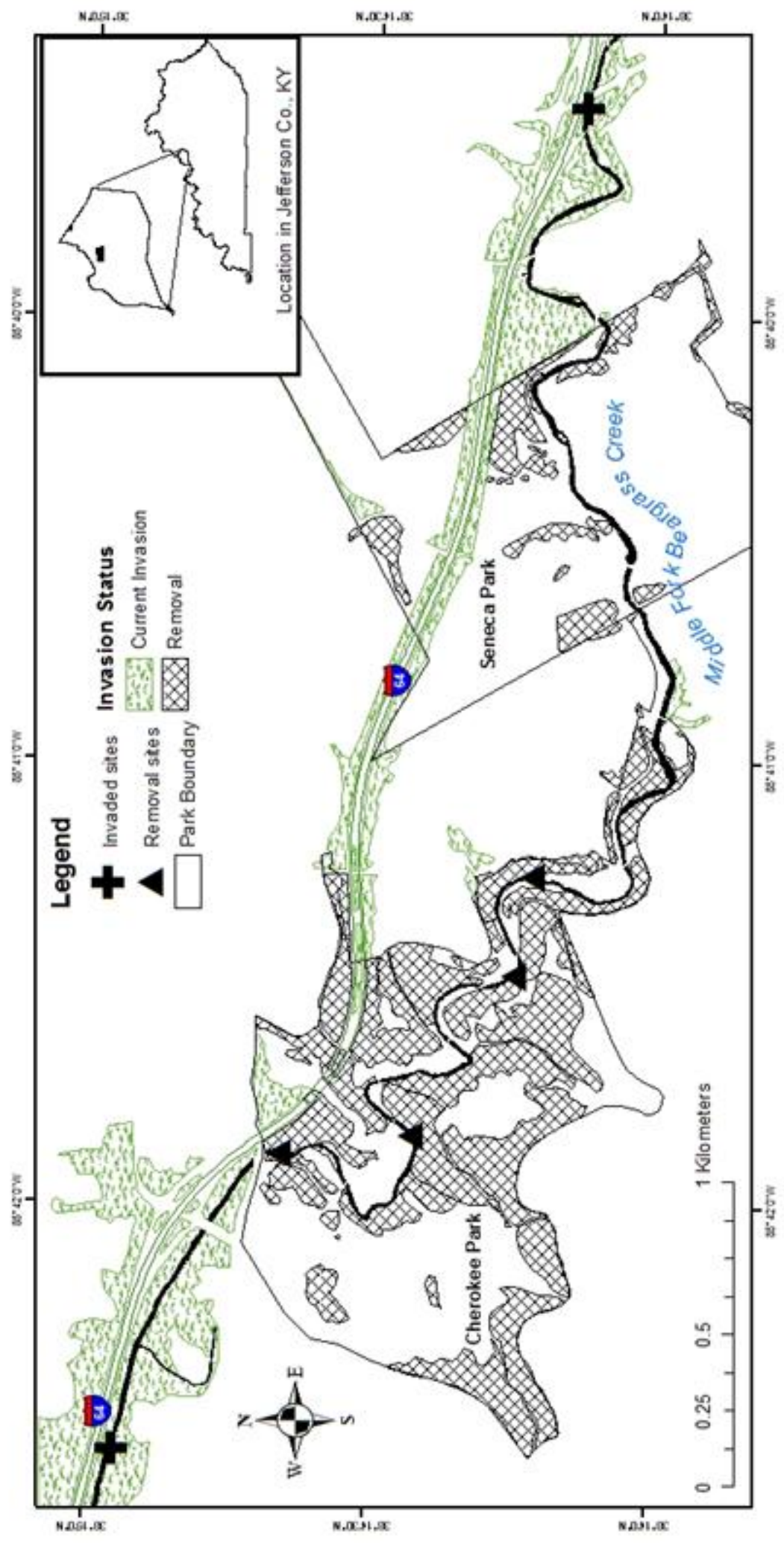

Figure 2-1. Map of field sites. 

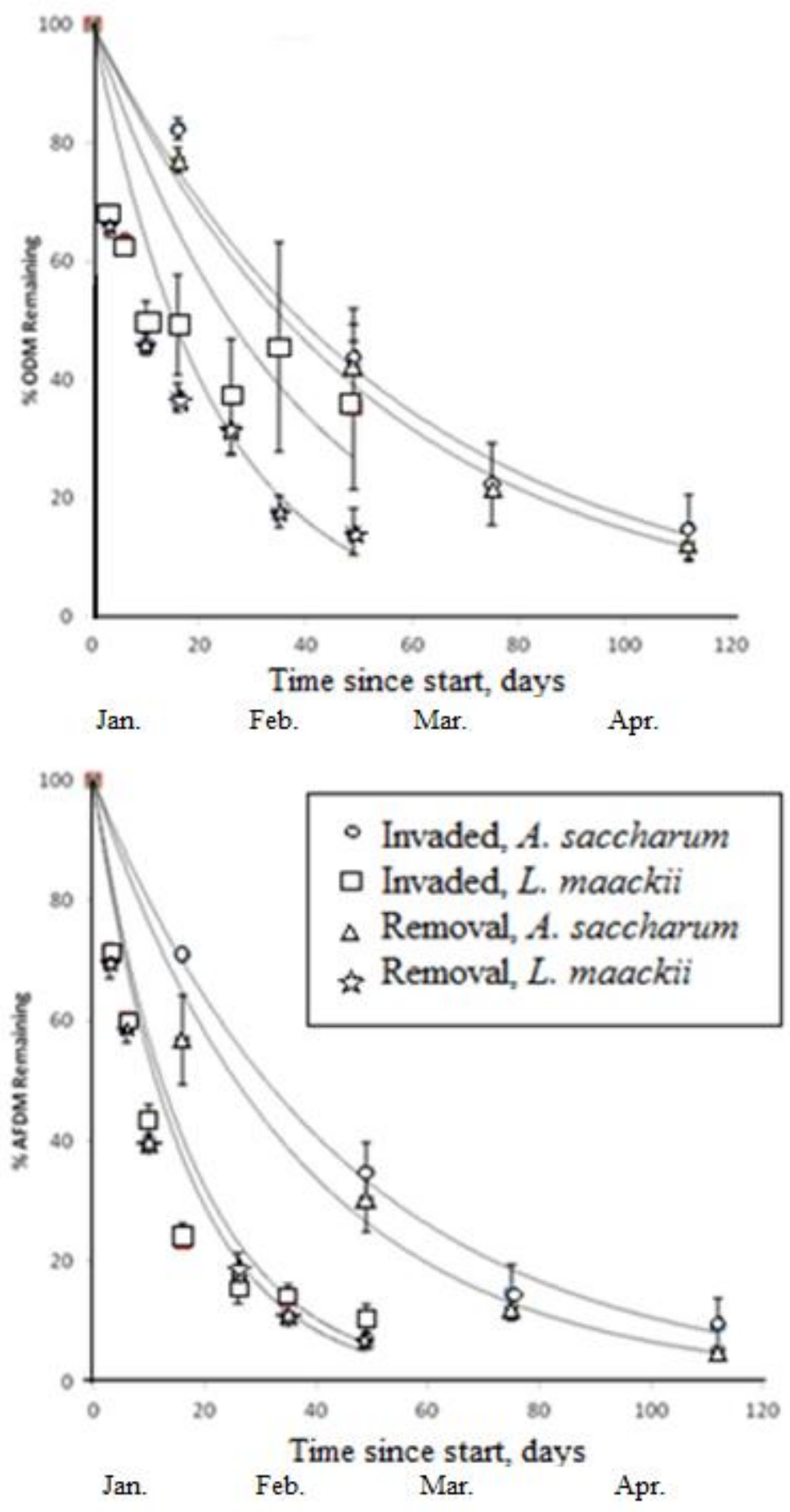

Figure 2-2. Percent ODM (oven dry mass) and AFDM (ash-free dry mass) remaining, mass loss curve. Error bars indicate $\pm 1 \mathrm{SE}$. 

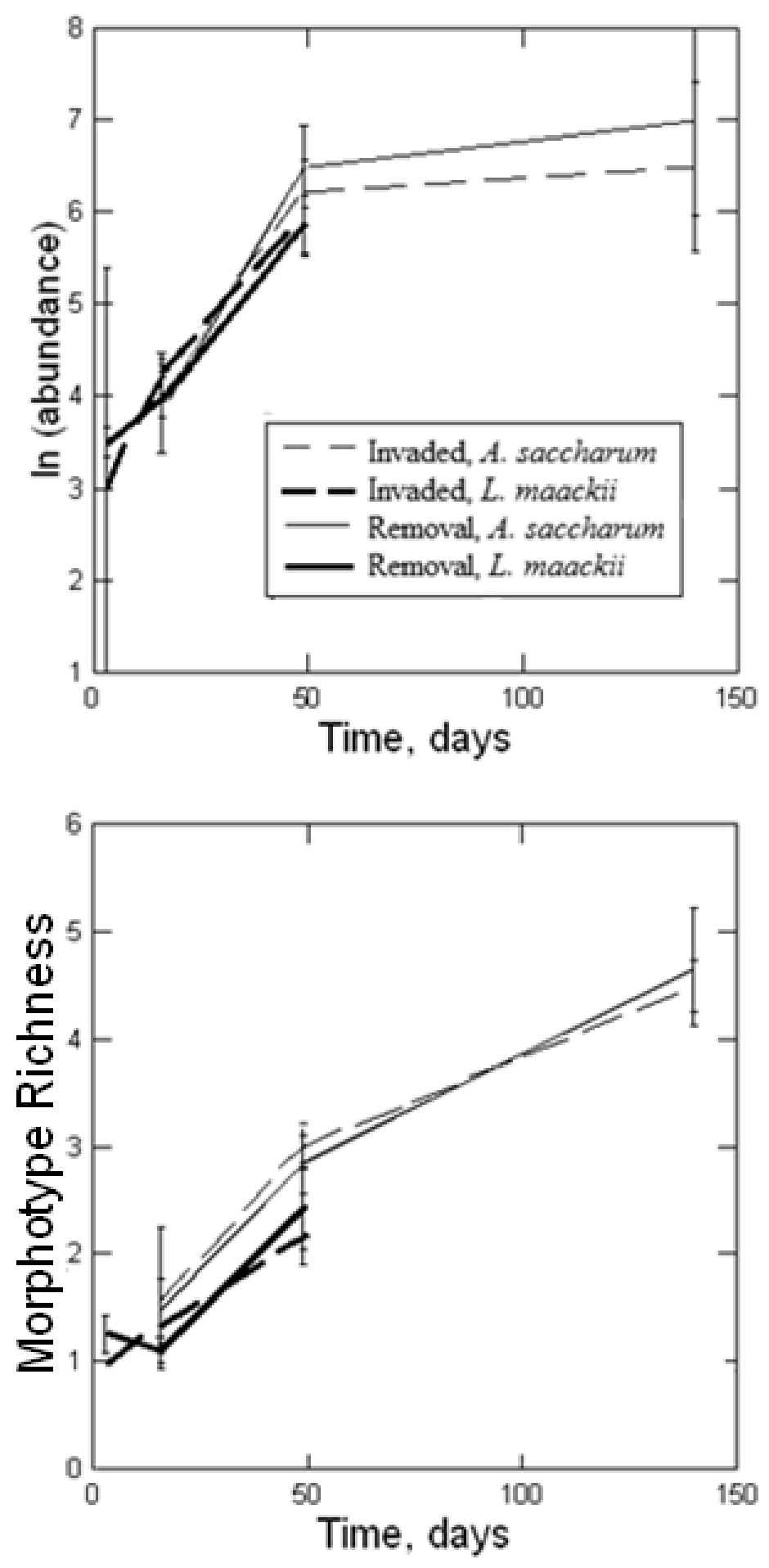

Figure 2-3. Average macroinvertebrate abundance per site and average morphotype richness per replicate. Error bars indicate $\pm 1 \mathrm{SE}$. 


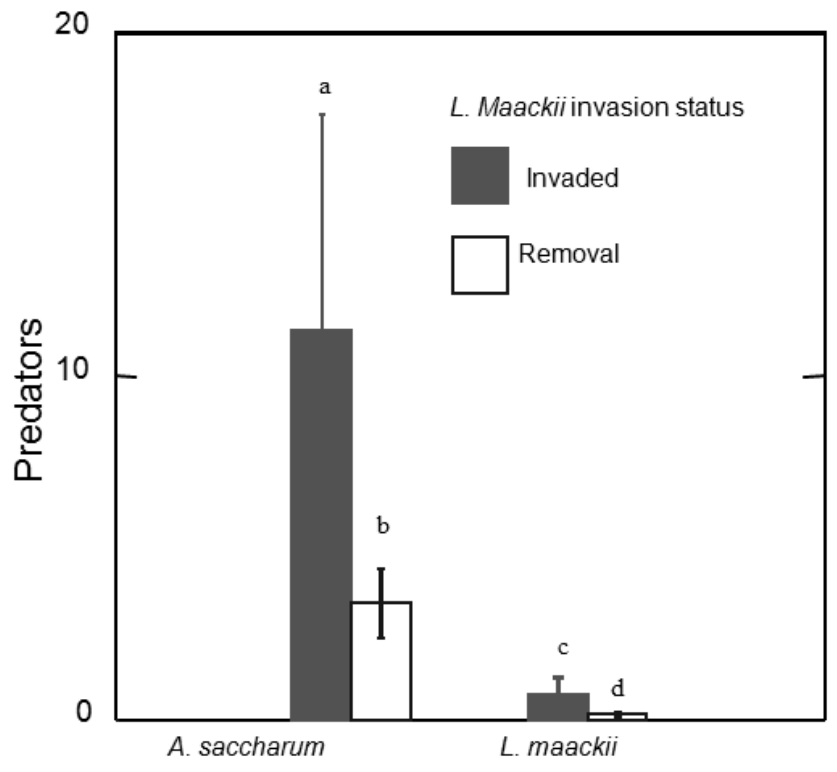

Figure 2-4. Average number of predators per treatment, day 49. Error bars indicate \pm 1 SE. 

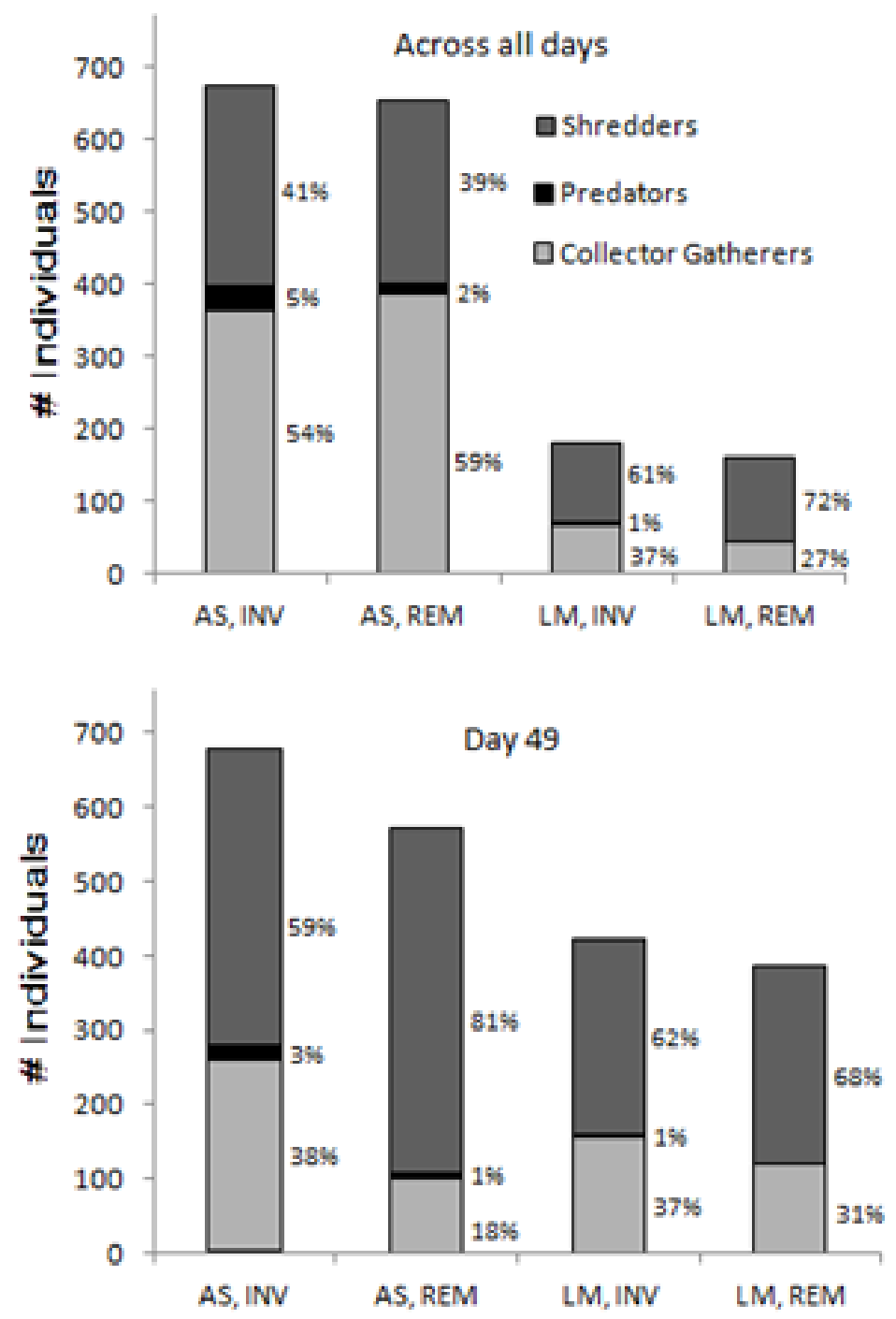

Figure 2-5. Average number of invertebrates per site per collection day, by FFG.

Collector filterers and scraper gatherers are not represented due to low abundances. 


\section{CHAPTER 3: CONCLUSION}

The results of this study (Chapter 2) indicate that Lonicera maackii can have direct effects on in-stream leaf litter decomposition rates and associated macroinvertebrate communities. Lonicera maackii leaf litter decayed about twice as quickly as the native A. saccharum litter and supported fewer invertebrates. Lonicera maackii also indirectly affected the predator functional feeding group of macroinvertebrates as a result of the location of litter near areas of L. maackii invasion. The effects on macroinvertebrate communities were amplified by the short residence times of L. maackii litter, resulting in even smaller and less diverse invertebrate communities over time. In order to gain more insight into these intricate processes, follow-up studies should be performed.

If I were to perform this study again, I would change the following aspects of the experimental design to get more interesting results. I would increase the number of sites along Beargrass Creek and set equal numbers of $L$. maackii invaded and removal plots. I would also schedule more collection dates to compare associations of both species of litter on the same day. More species of native litter could be included in order to get a more realistic insight into the overall effects of L. maackii. Furthermore, I would perform tests on the incubated leaf litter samples to get approximations of fungal and bacterial biomass and microbial respiration as a proxy for heterotrophic microbial 
activity. Doing so would help explain differences in macroinvertebrate abundance and FFG structure.

Although the abundance of invertebrates increased significantly with time, a calculation of number of invertebrates per gram leaf litter indicated that many of these packs had far more invertebrates than could have been supported by the extremely small amount of litter leftover toward the end of the study. Some of these invertebrates could have been using the mesh bag as habitat rather than feeding on the litter. This could have made additional noise in the data, and possibly confounded subtle changes in invertebrate communities. In order to avoid this in the future, I would set control mesh bags with no litter in order to account for invertebrates that use the bags as habitat over the entire decomposition period.

Lonicera maackii could potentially influence invertebrates outside of leaf packs, so collecting benthic samples throughout the year would allow us to better understand these changes. Additionally, I would add sites in pristine, non-invaded areas. In doing so I would calculate multi-metric macroinvertebrate bioassessment indices as an indicator of stream health. High density L. maackii invasion has also been found to be correlated with reduced primary production of nearby native tree species, resulting in overall decreased foliar output (Trammell et al. 2012). This could potentially alter nutrients that would be available to invertebrates throughout the winter and spring. I would design a study that investigates these effects on aquatic processes by measuring standing litter and associated invertebrates in invaded and removal plots. 
Finally, one reason we did not detect sizable indirect effects of L. maackii invasion could have been due to the scale of the project. We know from the GIS study that large stretches of Beargrass Creek are invaded, while some other sizable stretches do not have L. maackii present. We could add some sites that are in larger patches of uninvaded, invaded, or recently removed stretches of stream, possibly across more watersheds. 


\section{REFERENCES}

Allison SD, Vitousek PM (2004) Rapid nutrient cycling in leaf litter from invasive plants in Hawai'i. Oecologia 141: 612-619

Arthur MA, Kuchle CR, Bray SR, McEwan RW (2012) The influence of the invasive shrub, Lonicera maackii, on leaf decomposition and microbial community dynamics. Plant Ecology 213: 1571-1582

Ashton IW, Hyatt LA, Howe KM, Gurevitch J, Lerdau MT (2005) Invasive species accelerate decomposition and litter nitrogen loss in a mixed deciduous forest. Ecological Applications: a Publication of the Ecological Society of America 15: 1263

Bailey JK, Schweitzer JA, and Whitham TG (2001) Salt cedar negatively affects biodiversity of aquatic macroinvertebrates. Wetlands 21: 442-447

Beargrass Creek Watershed Council (2005) Beargrass Creek Watershed: State of the Streams. Informational brochure

Blair JM (1988) Nitrogen, sulfur, and phosphorus dynamics in decomposing deciduous leaf litter in the Southern Appalachians. Soil Biol. Biochem 20: 693-701

Blair BC, Stowasser A (2009) Impact of Lonicera maackii on decomposition rates of native leaf litter in a southwestern Ohio woodland. Ohio J. Sci. 109: 43-47

Bryer PJ, Scoggins M, McClintock NL (2010) Coal-tar based pavement sealant toxicity to freshwater macroinvertebrates. Environmental Pollution 158:1932-1937

Carreiro MM, Zipperer WC (2011) Co-adapting societal and ecological interactions following large disturbances in urban park woodlands. Journal of Austral Ecology 36: 904-915

Chadwick MA, Dobberfuhl DR, Benke AC, Huryn AD, Suberkropp K, Thiele JE (2006) Urbanization affects stream ecosystem function by altering hydrology, chemistry, and biotic richness. Ecological Applications : a Publication of the Ecological Society of America 16: 1796-807

Cipollini D, Stevenson R, Enright S, Eyles A, Bonello P (2008) Phenolic metabolites in leaves of the invasive shrub, Lonicera maackii, and their potential phytotoxic and anti-herbivore effects. J. Chem. Ecol 34:144-152 
Covich AP, Palmer MA., Crowl TA (1999) The role of benthic invertebrate species in freshwater ecosystems: zoobenthic species influence energy flows and nutrient cycling. BioScience 49: 119-127

Dorning M, Cipollini D (2006) Leaf and root extracts of the invasive shrub, Lonicera maackii, inhibit seed germination of three herbs with no autotoxic effects. Plant Ecology 184: 287-296

Exec. Order No. 13,112, 64 Fed. Reg. 6183. 1999.

Godoy O, Castro-Díez P, Van Logtestijn RS, Cornelissen JH, Valladares F (2010). Leaf Litter Traits of Invasive Species Slow down Decomposition Compared to Spanish Natives: A Broad Phylogenetic Comparison. Oecologia. 162: 781-790

Gould AMA, Gorchov DL (2000). Effects of the exotic invasive shrub Lonicera maackii on the survival and fecundity of three species of native annuals. American Midland Naturalist 144: $36-50$

Going BM, Dudley TL (2008). Invasive riparian plant litter alters aquatic insect growth. Biological Invasions 10: 1041-1051

Guo LB, Sims REH (2001) Effects of light, temperature, water and meatworks effluent irrigation on eucalypt leaf litter decomposition under controlled environmental conditions. Applied Soil Ecology 17: 229-237

Gulis V, Suberkropp K (2003) Leaf litter decomposition and microbial activity in nutrient-enriched and unaltered reaches of a headwater stream. Freshwater Biology 48: 123-134

Gurtz ME, Tate CM (1988) Hydrologic Influences on Leaf Decomposition in a Channel and Adjacent Bank of a Gallery Forest Stream. American Midland Naturalist 120: $11-21$

Hata K, Kachi N, Kato H (2012) Leaf litter of the invasive Casuarina equisetifolia decomposes at the same rate as that of native woody species on oceanic islands but releases more nitrogen. Weed Research 52: 542-550

Hutchinson TF, Vankat JL (1997) Invasibility and effects of Amur honeysuckle in southwestern Ohio forests. Conservation Biology 11: 1117-1124

Imberger SJ, Walsh CJ, Grace MR (2008) More microbial activity, not abrasive flow or shredder abundance, accelerates breakdown of labile leaf litter in urban streams. Journal of the North American Benthological Society 27: 549-561

Kennedy TA, Hobbie SE (2004) Saltcedar (Tamarix ramosissima) invasion alters organic matter dynamics in a desert stream. Freshwater Biology 49: 65-76 
Konrad CP, Booth DB (2005) Hydrologic changes in urban streams and their ecological significance. American Fisheries Society Symposium 47: 157-277

Krutzweiser D, Muto E, Holmes S, Gunn J (2010) Effects of upland clearcutting and riparian partial harvesting on leaf pack breakdown and aquatic invertebrates in boreal forest streams. Freshwater Biology 55:2238-2252

KYTC (Kentucky Transportation Cabinet) Projects Archive (1909-Present). 2008. Available at: http://kytcgis.ky.gov/proiectarchive/viewer.htm

Lagrue C, Kominoski JS, Danger M, Baudoin JM, Lamothe S, Lambrigot D, Leferf A (2011) Experimental shading alters leaf litter breakdown in streams of contrasting riparian canopy cover. Freshwater Biology 56: 2059-2069

Lewis SE, Brown AV (2010) Comparative Leaf Decomposition Rates Including a NonNative Species in an Urban Ozark Stream. Journal of the Arkansas Academy of Science 64: 92-96

Lindeman, R L (1942) The trophic-dynamic aspect of ecology. Ecology 23: 399-417

Luken J O, Thieret JW (1996) Amur honeysuckle, its fall from grace. Lessons from the introduction and spread of a shrub species may guide future plant introductions. BioScience 46: 18-24

Masters JA, Bryant AN, Carreiro MM, Emery SM (in prep) The impacts of invasive bush honeysuckle (Lonicera maackii: Caprifoliaceae) removal on arthropod communities

Melillo JM, Aber JD, Muratore JF (1982) Nitrogen and Lignin Control of Hardwood Leaf Litter Decomposition Dynamics. Ecology 63, 621-626

Merritt RW, Cummins KW, Berg MB (2008) An introduction to the aquatic insects of North America, 4th edn. Kendall/Hunt, Iowa

Miller KE, Gorchov DL (2004) The invasive shrub, Lonicera maackii, reduces growth and fecundity of perennial forest herbs. Oecologia 139: 359-375

McNeish RE, Benbow ME, McEwan RW (2012) Riparian forest invasion by a terrestrial shrub (Lonicera maackii) impacts aquatic biota and organic matter processing in headwater streams. Biological Invasions 14: 1881-1893

Meyer JL, Likens GE (1979) Transport and transformation of phosphorus in a forest stream ecosystem. Ecology 60: 1255-1269

National Park Service (NPS) (2013) Shrubs and Subshrubs: Amur Honeysuckle. Available: http://www.nps.gov/plants/alien/pubs/midatlantic/loma.htm. Accessed 2013 May 29 
Peterson RC, Cummins KW (1973) Leaf processing in a woodland stream. Freshwater Biology 4:345-368

Pimentel D, Zuniga R, Morrison D (1995). Update on the environmental and economic costs associated with alien-invasive species in the United States. Ecological Economics 52:273-288

Pond GJ, Call SM, Brumley JF, Compton MC (2003) The Kentucky Macroinvertebrate Bioassessment Index: Derivation of Regional Narrative Ratings for Wadeable and Headwater Streams. Kentucky Department for Environmental Protection, Division of Water, Frankfort, Kentucky

Reid MG, Barmuta LA (1999) Comparisons of benthic communities adjacent to riparian natice eucalypt and introduced willow vegetation. Freshwater Biology 47: 359374

Reinhart KO, VandeVoort R (2006) Biodiversity Research: Effect of native and exotic leaf litter on macroinvertebrate communities and decomposition in a western Montana stream. Diversity \& Distributions 12: 776-781

Samways MJ, Sharratt NJ, et al. (2011) Effect of alien riparian vegetation and its removal on a highly endemic river macroinvertebrate community. Biological Invasions 13(6): 1305-1324

Shouse M, Liang L, Fei S (2013) Identification of understory invasive exotic plants with remote sensing in urban forests. International Journal of Applied Earth Observation and Geoinformation 21: 525-534

Swan CM, Healey B, Richardson DC (2008) The role of native riparian tree species in decomposition of invasive tree of heaven (ailanthus altissima) leaf litter an an urban stream. Ecoscience 15(1): 27-35

Thorp JW, Covich AP (2001) Ecology and classification of North American freshwater invertebrates, 2nd edn. Academic Press, San Diego

Trammell T, Carreiro MM (2011) Vegetation composition and structure of woody plant communities along urban interstate corridors in Louisville, KY, U.S.A. Urban Ecosystems 14: 501-524

Trammell T L, Ralston HA, Scroggins SA, Carreiro MM (2012) Foliar production and decomposition rates in urban forests invaded by the exotic invasive shrub, Lonicera maackii. Biological Invasions14: 529-545

Triska FJ, Sedell JR, Cromack K, Gregory SV, McCorison FM (1984) Nitrogen Budget for a Small Coniferous Forest Stream. Ecological Monographs 54: 119-140

U.S. Department of Agriculture (USDA), 2013, PLANTS Profile: Lonicera maackii (Rupr.) Herder, accessed June 28, 2013, at URL 
http://plants.usda.gov/java/profile?symbol =loma6

U.S. Geological Survey (USGS), 2013, National Water Information System data available on the World Wide Web (USGS Water Data for the Nation), accessed Feb 20, 2013, at URL http://waterdata.usgs.gov/nwis.annual

Vannote RR, Minshall GW, Cummins KW, Sedell JR, Cushing CE (1980) The river continuum concept. Canadian Journal of Fisheries and Aquatic Sciences 37: 130137

Watling JI, Hickman CR, Orrock JL (2011) Predators and invasive plants affect performance of amphibian larvae. Oikos 120: 735-739

Webster JR, Benfield EF (1986) Vascular plant breakdown in freshwater ecosystems. Annual Review of Ecology and Systematics 17:567-594 


\section{APPENDIX}

Appendix A. Average number of each taxon per site per collection on day 49 and across all days. Functional feeding group (FFG): Collector filterers $(\mathrm{CF})$, collector gatherers $(\mathrm{CG})$, predators $(\mathrm{P})$, scraper gatherers $(\mathrm{SG})$, and shredders $(\mathrm{SH})$.

\begin{tabular}{|c|c|c|c|c|c|c|c|c|c|}
\hline \multirow[b]{2}{*}{ Taxon } & \multirow[b]{2}{*}{ FFG } & \multicolumn{2}{|c|}{$\begin{array}{c}\text { Acersaccharum } \\
\text { litter in inw aded } \\
\text { site } \\
\end{array}$} & \multicolumn{2}{|c|}{$\begin{array}{c}\text { Acersaccharwm } \\
\text { litter in remov al } \\
\text { site } \\
\end{array}$} & \multicolumn{2}{|c|}{\begin{tabular}{|c|} 
Lonicera \\
maackni litter in \\
inv aded site \\
\end{tabular}} & \multicolumn{2}{|c|}{$\begin{array}{l}\text { Loniceramaachä } \\
\text { litter in remov al } \\
\text { site } \\
\end{array}$} \\
\hline & & day 49 & total & day 49 & total & day 49 & to tal & day 49 & to tal \\
\hline Ancylidae & SG & 0 & 0.17 & 0.25 & 0.17 & 0 & 0 & 0 & 0 \\
\hline Araneae & $\mathrm{P}$ & 0 & 0.50 & 0 & 3.17 & 0 & 0 & 0 & 0 \\
\hline Asellidae & SH & 393.50 & 26667 & 457.75 & 252.88 & 263.00 & 11033 & 262.75 & 113.75 \\
\hline Cambaridae & SH & 0 & 0 & 0 & 0.25 & 0 & 0 & 0 & 0 \\
\hline Chironomidae & $\mathrm{CG}$ & 55.00 & 26483 & 31.25 & 339.67 & 22.50 & 11.00 & 52.75 & 18.92 \\
\hline Coenagrioridae & $\mathrm{P}$ & 9.00 & 4.83 & 0.50 & 1.67 & 3.50 & 1.83 & 0.25 & 0.08 \\
\hline Collem bola & $\mathrm{CG}$ & 1.00 & 7.83 & 0 & 1.75 & 0.50 & 2.83 & 0.25 & 1.67 \\
\hline Curculionidae & $\mathrm{SH}$ & 0 & 0 & 0 & 0.08 & 0 & 0 & 0.25 & 0.08 \\
\hline Cyclopoidea & $\mathrm{CF}$ & 3.00 & 1.00 & 0.50 & 0.17 & 0.50 & 0.17 & 1.00 & 0.50 \\
\hline Elmidae & $\widehat{\mathrm{CG}}$ & 0 & 0 & 0 & 0.08 & 0 & 0 & 0 & 0 \\
\hline Ephemeroptera & $\mathrm{CG}$ & 0 & 0 & 0.25 & 0.08 & 0 & 0 & 0 & 0 \\
\hline Gammaridae & $\mathrm{SH}$ & 5.50 & 11.17 & 6.00 & 2.33 & 0 & 0 & 1.25 & 0.42 \\
\hline Heptageniidae & $\mathrm{SG}$ & 0.50 & 0.33 & 0 & 0 & 0 & 0 & 0 & 0 \\
\hline Hirudinea & $\mathrm{P}$ & 0 & 4.50 & 0 & 0.33 & 1.00 & 0.33 & 0 & 0 \\
\hline Hydrachrida & $\mathrm{P}$ & 0 & 1.00 & 0 & 0.92 & 0 & 0 & 0 & 0 \\
\hline Hydradae & $\mathrm{P}$ & 0 & 0 & 0 & 0.67 & 0 & 0 & 0 & 0 \\
\hline Hydrobaidae & SG & 0 & 0 & 0 & 0.08 & 0 & 0 & 0.25 & 0.08 \\
\hline Hydroptilidae & SG & 0 & 0 & 0 & 0.17 & 0 & 0 & 0 & 0 \\
\hline Leptophlebiidae & $\mathrm{CG}$ & 0.50 & 0.17 & 0.25 & 0.08 & 0 & 0 & 0.75 & 0.25 \\
\hline Lutrochidae & $\mathrm{SH}$ & 0 & 0.17 & 0 & 0 & 0 & 0 & 0 & 0 \\
\hline Macrovellidae & $\mathrm{P}$ & 0 & 1.50 & 0 & 0 & 0 & 0 & 0 & 0 \\
\hline Nem atom orpha & $\mathrm{P}$ & 0 & 0.17 & 0 & 0 & 0 & 0 & 0 & 0 \\
\hline Oligochaeta & $\overline{\mathrm{CG}}$ & 198.00 & 84.33 & 65.50 & 42.50 & 129.50 & 52.50 & 64.25 & 22.58 \\
\hline Physidae & $\overline{\mathrm{CG}}$ & 3.50 & 3.50 & 3.00 & 1.71 & 1.50 & 0.50 & 0.50 & 0.17 \\
\hline Planariidae & $\mathrm{P}$ & 8.50 & 21.33 & 2.00 & 2.33 & 0 & 0 & 0.75 & 0.33 \\
\hline Planorbidae & $\mathrm{CG}$ & 0 & 0 & 0.50 & 0.54 & 0.50 & 0.17 & 0.50 & 0.17 \\
\hline Pleuroceridae & SG & 0 & 0.33 & 1.00 & 1.38 & 0 & 0 & 0 & 0 \\
\hline Psephenidae & SG & 0 & 0.17 & 0 & 0.08 & 0 & 0 & 0 & 0 \\
\hline Psychodidae & $\overline{\mathrm{CG}}$ & 0 & 1.00 & 0 & 0 & 0.50 & 0.17 & 0.25 & 0.08 \\
\hline Ptilodactylidae & $\mathrm{SH}$ & 0 & 0 & 0 & 0.08 & 0 & 0 & 0.25 & 0.08 \\
\hline Scathophagidae & $\mathrm{SH}$ & 0 & 0.17 & 0 & 0.17 & 0 & 0 & 0 & 0 \\
\hline Scirtidae & SG & 0 & 0 & 0 & 0 & 0 & 0 & 0 & 0.08 \\
\hline Sphaeriidae & $\mathrm{CF}$ & 0 & 0 & 0.25 & 0.63 & 0 & 0 & 0.25 & 0.08 \\
\hline Staphylinidae & $P$ & 0 & 0.17 & 2.50 & 1.13 & 0 & 0 & 0 & 0.08 \\
\hline Tipulidae & $\mathrm{SH}$ & 0 & 0 & 0 & 0.17 & 0 & 0 & 0.25 & 0.08 \\
\hline TOTAL & & 678.00 & 67583 & 571.50 & 655.25 & 423.00 & 17983 & 386.50 & 15950 \\
\hline
\end{tabular}




\title{
CURRICULUM VITAE
}

\author{
Catherine A. Fargen \\ Department of Biology \\ Life Sciences 139 \\ University of Louisville \\ Louisville, KY 40202
}

\section{EDUCATION}

B.S. Biology, University of Louisville. Louisville, KY 2010

\section{PROFESSIONAL POSITIONS}

Physical Science Lab Technician, U.S. Geological Survey. (04/11- present)

Lab Technician and Field Assistant, Lab of Dr. Sarah Emery, University of Louisville $(05 / 08-09 / 11)$

\section{SCHOLASTIC AND PROFESSIONAL HONORS}

Graduate Student Union Research Grant, University of Louisville 2013, \$100

Vice President for Research Undergraduate Research Scholar Grant, University of Louisville 2010, \$500

Time-off Recognition Award, U.S. Geological Survey. Performance based, 2012

STAR Award, U.S. Geological Survey. Performance based, 2011

\section{POSTER PRESENTATIONS}

Fargen, C.A. and S.M. Emery. 2011. Preference of a generalist insect herbivore for invasive versus native plant hosts. University of Louisville Undergraduate Research Symposium. Louisville, KY 